\title{
Globalization and the Wider Black Sea Area: Interaction with the European Union, Eastern Mediterranean and the Middle East
}

\author{
Roberto Aliboni
}

This article deals with the relationship between globalization trends and the Black Sea Economic Cooperation (BSEC) region. Its key argument is that BSEC role and dynamics with respect to globalization are strictly related to and largely dependent on the relationship between BSEC and the European Union (EU). The article assumes that BSEC performance in the framework of globalization is related to and mostly affected by its relations with the EU. These relations are about to be regulated by the European Neighbourhood Policy (ENP) recently adopted by the EU with a view to tackling the consequences of the 2004 Eastern and Southern enlargement. The ENP will affect the BSEC directly and indirectlythat is by means of EU policies towards BSEC itself as well as those towards BSEC neighbouring regions and countries. In particular, it will affect two regions that are very significant to the BSEC: the Eastern Mediterranean and the Middle East. The article comments on such indirect effects and concludes by recommending the establishment of contractual relations between the EU and the BSEC in a form similar to that of the Northern Dimension, so as to allow the BSEC to take due advantage from the ENP process.

\section{Globalization and Regional Integration: The Case of the Black Sea Economic Cooperation}

The Black Sea Economic Cooperation (BSEC) has two principal interrelated tasks. The first relates to its very matrix-namely its aim of acting as a confidence-building measure in the framework of the Organisation of Security and Cooperation in Europe (OSCE) process. In fact, this is what is stressed by the BSEC founding documents. ${ }^{1}$ Within the framework of the European architecture, as ultimately enshrined in the Paris Charter, the building up of solid and structured regional economic cooperation and/or

Correspondence to: Roberto Aliboni, Mediterranean and Middle East Programme, Istituto Affari Internazionale, via A. Brunetti 900185, Rome, Italy. E-mail: r.aliboni@iai.it 
integration frameworks is intended to be a definite contribution to peace and stability. In this sense, the economic activities of BSEC are in principle instrumental to the attainment of these political aims. Still, they are equally important and must be considered as an end in themselves. The BSEC is a typical process of regional economic cooperation, an example of regionalism in the framework of globalization, very similar to many other ongoing regional undertakings in Europe and the world. This is the second task of BSEC.

The regional processes of economic cooperation and integration, the BSEC being no exception, used to include both political and economic factors as sides of the same coin. The two sides cannot be easily separated and, for this reason, they are considered in a 'political economy' perspective- that is, a perspective that tries to combine the analysis of both political and economic factors. In this perspective, the economic performance is linked to the issue of governance. In fact, the question internationally debated, particularly in the last few years, is whether or not regions contribute to global governance. While globalization is an objective trend, it must be governed if it is to be beneficial and its adverse effects are to be smoothed over. What is today's role of a proliferating economic regionalism with respect to global governance? Is it consistent or opposed to the latter? Is regionalism systemic with respect to international free trade and economic globalization, or is it anti-systemic?

According to different schools of thought, ${ }^{2}$ regionalism can be cooperative or conflict-oriented. This can take place either accidentally, thanks to particular circumstances, or intentionally, as a result of discussion and deliberation. There are authors who see regionalism as an offensive response to the present conditions of the international economic system, a response similar to the creation of discriminatory and exclusive trade blocs and the large application of protectionism that prevailed in the $1930 \mathrm{~s}$ when the first wave of regionalism took place. Others look at it as a response that is cooperative in its character (or will so prove at the end of the day). This cooperative regionalism seems to characterize both the second (1950s-1970s) and the present, third waves.

There is an important difference between the second and the present waves of regionalism with respect to international governance. The second wave took place in a situation in which the United States provided the necessary 'public goods' to assure the equilibrium of the international system. In this system, regionalism could be regarded as a stage of transitional protectionism directed at assuring national development or overcoming local imbalances without putting into question, however, the system's hegemonic governance. The final result was a reinforcing of the overall system. Governance was essentially global. With the end of the United States hegemony, the international economic system has shifted in an enduring post-hegemonic situation in which the supply of public goods is short and cannot meet the demand. According to authors, regionalism must be regarded, first of all, as a response to such a shortage. Regionalism thus acts as a mechanism trying to provide locally the public goods that the system cannot. If this is accepted, regionalism results in being highly consistent with globalization as an economic trend. On the political side of the coin, the economic consistency between globalization and regionalism means that regionalism plays an essential role in global governance by providing an intermediate level of decision making and management and generating public goods between the global and the national level. 
This author shares the view that current regionalism is consistent with globalization and contributes to international governance by complementing global and national governance. BSEC, in particular, is definitely in tune with such systemic regionalism, as regularly illustrated by its statements and its policies. In the BSEC, we can find all the motivations for creating a regional supplementary engine to development and modernization 'in terms of location (trade and investment, saving in transport and economy of scale)', of chances to expand and train firms thanks to a larger market size, and of capabilities for learning to cope with international competition (Telò 2001: 117). At the same time, the BSEC members look very clearly at these regional steps in a wider perspective, be it the European or the global space. BSEC is a factor in what is called 'open regionalism'. The features of BSEC correspond to those of the third wave: '[T]he heterogeneity of participating countries, the outward-looking approach of members, the domestic liberalization not only of goods but also of services, which involves new rules for investments and the provision of competition policy and technical standards' (Guerrieri and Falautano 2000: 16-17). BSEC is a globally orientated region, using regionalism to carry out successfully its transition towards globalization.

\section{BSEC and the European Union: Regions and Sub-regions in Europe}

The correlation of BSEC with globalization is not (or is not always) a direct one. It cannot take place in isolation. The exposure of the BSEC region to globalization takes place in a given context, which comprises other regional formations and networks of economic and political relations. In other words, it takes place in a given geopolitical regional environment. This regional environment includes two main references: on the one hand, Central Asia and the Middle East (in particular, the Upper Gulf area), and on the other, the expanding area of the European Union (EU). The BSEC is a natural bridge between the two areas and is bound to work as a platform connecting and developing the space between the EU and what the United States calls the 'Greater Middle East'. The success of the BSEC is linked to a virtuous circle between its capacity to attract foreign investment and to invest profits in members' broad economic development.

In its role as bridge, BSEC has a clear global attitude as an investment-receiving area (from the EU as well as the United States). At the same time, its attitude has a more regional character when it comes to developing and trading the outcome of investment. This outcome is naturally directed at domestic markets and, most of all, to the greater EU area. The EU and BSEC areas have a clear major complementary character. The latter is strengthened by non-economic factors as well. In fact, it must be pointed out that the BSEC is a bridge also for a relevant number of soft security issues such as international crime and trafficking. This fact increases its complementary character with the EU area and stresses the political economy perspective in which the BSEC has to be taken into consideration in the realm of globalization.

Against this background, one has to say that the 'bridge' role of BSEC is not neutral or equidistant between its two shores. As a matter of fact, the BSEC is subjected to a fatal attraction of integration and cooperation towards the greater EU area because of 
economic as well as political reasons. ${ }^{3}$ This EU bias of the BSEC is confirmed by a number of facts. The BSEC was created on the assumption that its members would not be prevented from pursuing their policies aimed at establishing specific relations with the EU. The status of its members' relations with the EU (see Table 1) illustrates very well this attraction or gravitation. At the end of the day, the expectation of a special relationship with the EU is definitely not a mystery: the BSEC's need and desire to develop and strengthen its relations with the EU appear regularly in its official documents. The Istanbul 2002 Decennial Declaration of the BSEC Heads of States and Governments, the resolution of the Foreign Ministers issued in Yerevan on 18 April 2003, and, lately, the Declaration on BSEC and the EU Cooperation adopted by the BSEC Council in Chisinau in October 2005 are illustrative of this. Following the Hellenic Chairmanship-in-Office of the BSEC (November 2004-May 2005), the BSEC decided to work more systematically on the BSEC-EU relations, establishing an 'ad hoc Group of Experts on BSEC-EU' with the mandate to produce a new platform for cooperation between the two organizations.

In conclusion, the role and status of the BSEC in the context of globalization seems twofold. On the one hand, BSEC has its own agenda, which is bound to take advantage of its geopolitical location as bridge between the EU and Central Asia/Middle East with a view to enhancing its resources and development. On the other hand, the BSEC is attracted by the EU area of integration since interests lie more towards this direction in general than towards the East. In other words, because of its geopolitical configuration, BSEC is confronted by two levels of globalization: globalization proper and a kind of regional globalization concerning its relations with the EU, its big neighbour. The EU generates public goods within the circle of Euro-Asian relations of which the BSEC can take advantage. The Euro can be regarded as one such public good. Another public good is the ENP network of agreements and institutions the EU is creating in Eastern Europe, the Balkans, Russia and the Mediterranean (as well as the financial resources ENP is going to provide and set in motion). Conversely, the role of BSEC in developing infrastructures and cooperating in sensitive sectors, such as environmental protection and soft security, provides advantages to the EU and contributes an appropriate regional articulation to European as well as global governance.

\section{The Response of the EU: The Neighbourhood Agenda}

What we have said so far suggests that the impact of globalization to the BSEC and its wider area regards mostly its relations with the EU. Further factors also have an impact on BSEC globalization, though, including United States relations with the Middle East. There is no doubt, however, that the EU is the most significant pole of BSEC attraction and, as a consequence, the most significant link the BSEC has to globalization.

While the BSEC is attracted to the EU, the reverse is definitely less true. In the past, there were times when the EU showed an interest in the BSEC-for example, when in 1997 the Commission aired a well articulated agenda for its action in the BSEC area (Commission of the European Communities 1997). The EU also funded a number of projects in the region. Most recently, there was a meeting in Brussels on 11 April 2005 


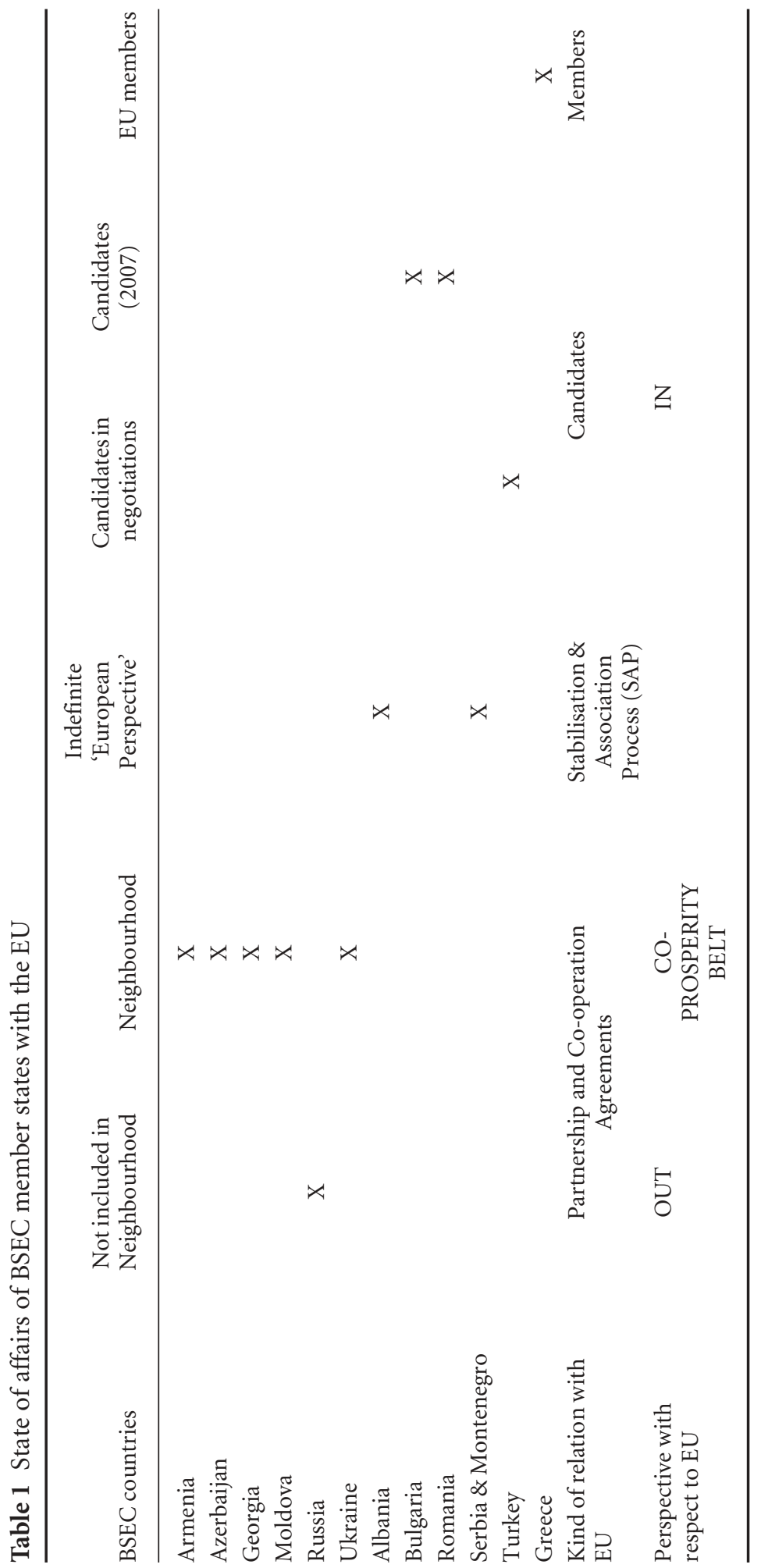


between BSEC Senior Officials and EU high-level representatives that seemed to bring in a more distinct EU interest towards the BSEC. ${ }^{4}$ Still, it remains true what Valinakis (1999: 54) said some years ago: 'EU involvement in the BSEC framework has ... been minimal.' In general, the EU is very supportive of sub-regional agreements of cooperation and integration. The political economy of regional integration broadly fits with the EU's very identity and is regarded by the EU—as well as the OSCE_-as an important instrument of economic development and conflict prevention. Still, Valinakis very aptly notes that so far the EU has been more successful in promoting and supporting sub-regionalism in the Northern and, to some extent, Central and Eastern Europe than in Southeastern Europe and the Black Sea area. This point of view is shared by subsequent analyses (Aydin 2005).

As of today, the ENP (the EU's agenda for re-ordering EU relations with neighbours in order to cope with the consequences of May 2004 enlargement) seems again to disregard the BSEC in casting out what the Commission calls 'A New Framework for Relations with our Eastern and Southern Neighbours'. The first document of the Commission on the ENP did not mention the BSEC at all. The last one, illustrating the ENP as a strategy, barely mentions it. ${ }^{5}$

What is the relevance of the new policy for the BSEC? One can respond to this question from a general point of view as well as from a BSEC specific perspective. Generally, one should highlight first that while the ENP aims for a deep integration by sharing with neighbours its internal market rules, its architecture corresponds to nothing more nor less than the longstanding instruments and aims of the association relations the EU has devolved towards its adjacent regions almost since its inception, with a view to promoting regional and inter-regional cooperation.

In principle, EU regionalism intends to foster relations among its partners at a regional level alongside bilateral relations with each one of them (at the end of the day, it is that purpose which makes inter-regionalism-especially between countries at different levels of development_compatible with globalism and global governance). In general, however, bilateral relations have increased far more than horizontal relations among partners. Results are mixed and very much dependent on the degree of partners' development. When partners are less developed, there is a polarization effect. Each associated country gets more interested in developing its economic and commercial relations with the EU rather than with its neighbours. The latter have usually little to offer compared to the EU, or relations with neighbours may be antagonistic. The economic power that the EU possesses acts as a dividing factor with respect to EU less developed partners.

Thus, the pattern of EU relations with its less developed neighbours tends to be inevitably a hub-and-spokes one. Horizontal integration and cooperation among EU associates gets neglected rather than upgraded. This has been the experience with the Maghreb, the Euro-Mediterranean Partnership (EMP) countries and, in general, with other inter-regional relations the EU has tried to foster in Central and Eastern Europe and the Balkans.

This effect of polarization is much less important when the partners are sufficiently developed economically or, more broadly speaking, when the partner regional 
organization is something that already works rather than something that has to be set up more or less from scratch. An example of the former is the EU's experience with the Northern Dimension. From the BSEC perspective, the implementation of the EU emerging Neighbourhood Policy can weaken the BSEC in two respects. First, the extreme differentiation of BSEC members' status vis-à-vis the EU (see Table 1) may weaken cohesion within BSEC itself. Second, while the new EU policy takes into consideration existing sub-regional frameworks of relations with its neighbours, such as the Euro-Mediterranean Partnership and the Northern Dimension, it does not take the BSEC convincingly into consideration. This may contribute to the weakening and division of the BSEC. In any case, from both points of view, while individual members of the BSEC would take advantage of the benefits that the EU Neighbourhood Policy promises, other members of the BSEC would not be able to do the same. Unless the BSEC is explicitly included in the new ENP, there will a discriminatory effect that may put at risk BSEC cohesion and rationale.

What is the best option for BSEC? Should it try to be included in the neighbourhood policy or not? In case it is excluded, the discrimination stemming from an uneven application of the ENP to individual BSEC members can compromise the very foundations of the organization. On the other hand, the inclusion in the neighbourhood framework may bring about a similar risk of polarization and fragmentation according to the huband-spokes pattern of relations that being included would seemingly generate. In both cases, there is a risk of fragmentation, if not dissolution or disruption. However, BSEC members have a relatively high level of development. Furthermore, it is a wellstructured and functioning regional organization and the members look willing to pursue their regional cooperation. Consequently, the best (or least damaging) option is inclusion in the neighbourhood scheme, whose polarization effects the BSEC should be able to counter successfully while enjoying neighbourhood advantages. This is the best option also from a global governance vantage-point as it preserves, along with BSEC's cohesion, a viable regional articulation in the area. Thus, this should be the option that BSEC institutions should support in their evolving relations with the EU.

\section{Eastern Mediterranean and the Middle East in the ENP Perspective}

How do developments discussed in previous sections interplay with Eastern Mediterranean and Middle Eastern areas? What is or would be the role of BSEC with respect to these areas in the EU neighbourhood policy perspective?

\section{The Eastern Mediterranean}

The Eastern Mediterranean concept remains partly heir to Cold War geopolitics when it focused on Cyprus, Greece, Turkey and other countries on the eastern shores of the Mediterranean being referred to as 'Levant', 'Near East' or 'Middle East'. Post-Cold War developments have tended to enlarge that concept to neighbouring areas and brought about the very existence of BSEC. Thus a new concept encompassing the above areas has emerged—-that of 'Greater Eastern Mediterranean'. 
The idea that the early Eastern Mediterranean area has expanded to a new wider area organized to attain stability and peace can be regarded as an important and positive factor in the framework of the dispute between Greece and Turkey and its attendant conflict in Cyprus. For sure, the BSEC has developed for the time being more as an economic than a political and security cooperation venture. While this option is consistent with the development of long-term capabilities of conflict prevention and management in the region, it has left them behind in the short term. In this sense, the BSEC has been unable to contribute to the management and solution of the TurkishGreek dispute or the Cyprus conflict. Still, there is no doubt that the presence of both Greece and Turkey in the BSEC has contributed to the ongoing 'détente' between the two countries (Lesser et al. 2001). Although the BSEC cannot be regarded as a specific factor for solving the dispute, the inclusion of both countries in a regional cooperative structure such as the BSEC has to be considered in itself as a factor contributing to a process of conflict prevention and resolution in the longer term.

With respect to the solution of the dispute, the inclusion of Turkey in the EU, beside Greece and Cyprus, could be regarded as a more effective alternative than the BSEC. As a matter of fact, however, this does not detract from the significance of BSEC for furthering cooperation between Turkey and Greece (and maybe Cyprus tomorrow). By the same token, cooperation with Russia remains an issue for the Baltic countries even after their inclusion in the EU and, to that purpose, the so-called 'Northern Dimension' will not cease to help cooperation in the area. Greece and Turkey (and maybe Cyprus) need a sub-regional dimension to develop their relations with the other BSEC countries anyway. In fact, while the solution of the disputes relating to the narrower Eastern Mediterranean area are of importance for EU security, this solution cannot come only thanks to the inclusion of all the stakeholders in the EU. Cooperation in the Greater Eastern Mediterranean area (i.e., the BSEC) would strongly contribute to such a solution by allowing for cooperation in a sub-region where Greece and Turkey-and Cyprus-have strong interests.

The Greater Eastern Mediterranean area can perform another cooperative task. The BSEC area is very important for Russia and relates to a set of significant political and economic Russian interests. For Russia, a degree of independence from the EU in dealing with its interests around the Black Sea basin is certainly welcome. For the EU, this flexibility in its relations with Russia would be helpful, especially since the BSEC is bound to develop into a pro-EU area.

A final point regards what the first Commission's communication on the ENP calls 'the management of the new external borders and transboundary flows'-mostly the problem of legal and illegal migration and soft security issues (e.g., international crime, drug trafficking, other kind of trafficking and the suppression of terrorism). While the ENP as a non-regionally structured entity did not help in tackling these issues, the BSEC is bound to be more cohesive in a case where it is encouraged to tackle soft security issues in its regional context. This would help the EU much more than any bilateral or hub-and-spokes pattern of cooperation in the fields involved.

In conclusion, the existence of a working regional space in the Black Sea area would combine positively with the EU in dealing with conflict in Eastern Mediterranean and 
other regional security issues, such as soft security ones. By the same token, it would ease and reinforce cooperation with individual countries, as in the case of Russia. A network of only bilateral EU relations with the individual countries of the region would be second best. If the impact of the EU neighbourhood policy were to trivialize the BSEC regional framework of cooperation, the emerging EU policy could be detrimental not only to the BSEC, but to the EU as well.

\section{The Middle East}

The EU has never considered the Middle East as a single area in the way the United States and Russia have done. EU policy towards this area is very fragmented. While the EU has developed significant common political approaches to the Mediterranean and the Near East (the Arab-Israeli Conflict), it has always maintained an extremely low profile with respect to the Gulf area. The EU never had any contractual relations with Iraq, but maintained very limited and low-level political relations. Regarding Iran, there is a political dialogue in the shape of the so-called 'critical dialogue'. Between the GCC countries and the EU there is a comprehensive agreement that contemplates a political dialogue as well as trade and economic relations that are considered by analysts undeveloped and unsatisfactory. Some European countries-namely the United Kingdom, France, Germany and, to some extent, Italy-have developed bilateral relations with Iran and or individual Gulf Cooperation Countries (GCCs). Yet, while the United Kingdom and France have always included the region in their strategic perspective, the other European countries have not. This absence has prevented EU policies from emerging (as in the case of Iraq and Iran) or from assuming a more adequate profile (as with the GCC). The task has been largely left to the United States and the European members of the United Nations Security Council (i.e., France and the United Kingdom).

The emerging ENP risks reinforcing the fragmentation of EU policies towards the Middle East and the ensuing lack of strategic perspective by consolidating its present distinction between the Southern Mediterranean and the other areas of the Middle East (Neugart and Schumacher, 'EU's Future Neighbourhood Policy', 169-192, and 'Geopolitical Implications'). The European official discourse keeps on attributing a special importance to the Southern Mediterranean for its security. However, the pattern of migration includes many Asiatic and African areas beside those of the Middle East and North Africa; transnational trends such as terrorism and Islamic extremism go well beyond the Levant and North Africa. When it comes to hard security issues, such as Weapons of Mass Destruction (WMD) proliferation or the Arab-Israeli Conflict, the distinction between the Mediterranean and the Middle East is without sense.

The lack of strategic perspective and the fragmentation of the EU Middle Eastern policies is essentially the outcome of its enduring deficit in the Common Foreign and Security Policy (CFSP). Unless the CFSP is developed within full communitarian rather than intergovernmental policy, the EU will not be able to have the necessary relations with the Middle East. In this sense, when the large belt of crises that surrounds the EU 
since the end of the Cold War - a belt that stretches from Central Asia to the Atlantic Ocean-is taken into consideration, it is evident that the area covered by the BSEC plays a significant role. The BSEC, as an organized area oriented to stability, development and peace, fills a vacuum the EU is unable to fill until it can get out of its political minority status by enforcing a real EU common security and foreign policy. The BSEC, in alliance with the EU, can perform a series of political and security functions with respect to an area the EU cannot manage by itself. In this sense, a downgrading of the BSEC within the context of the EU Neighbourhood Policy would not be a plus for the EU itself.

While there is no doubt that the stabilization and democratization of the Southern Mediterranean is an important, though strategically limited, asset for EU security and prosperity, Europeans should not overlook the fact that with respect to many European interests, such as the future of the Balkans, its relationship with Russia, and national interests of individual EU members, the BSEC area's stability, democratization and development is no less important than that of Southern Mediterranean. In both cases, a working regional organization helps the interests of the EU towards the areas involved and those beyond them. In this respect, it must be noted that while the BSEC is a functioning regional organization, the Southern Mediterranean is not and, sadly, is unlikely to be so in the near future.

\section{Conclusions}

The BSEC has a consistent and positive role in the context of globalization and, in this sense, contributes to global governance. The role of the BSEC region on the global scene is mostly affected by the EU. The emerging ENP may fragment and weaken the BSEC by including some of its members in the new policy and excluding others. This article argues that this is not convenient to the EU itself because the BSEC and the EU are complementary in a number of significant respects. Furthermore, for the sake of global governance, viable regions like the BSEC have to be strengthened rather than enfeebled. In this perspective, the article points out a number of arguments relating to the positive political and economic role of the BSEC with respect to the Middle East and the Eastern Mediterranean area.

At the end of the analysis carried out here, one can wonder what should be done. There is no doubt that, because of the extreme differentiation in the BSEC members with respect to the EU, setting out contractual relations between the EU and the BSEC may pose some challenges. In any case, the EU should recognize the role of the BSEC and give it an appropriate format as a condition to include it in the network of its emerging Neighbourhood policy. The Northern Dimension format seems more appropriate to shaping a viable EU-BSEC contractual relationship. Under this format, other EU members, further to Greece, might be interested in joining the BSEC-for instance, Italy, whose interests towards the Black Sea area are definitely more important than those towards the Mediterranean, Germany and maybe Cyprus. The Northern Dimension format has been very aptly pointed out by the Yerevan BSEC resolution. This resolution, however, has not found a convincing response from the EU as yet. 


\section{Acknowledgements}

This article is based on a paper presented at the conference on 'The New European Architecture in the 21st Century. Promoting Regional Co-operation in the Wider Black Sea Area: The BSEC Case', organized by the International Centre for Black Sea Studies (ICBSS) and the Hellenic Parliament in Milos (Greece) on 3-7 September 2003.

\section{Notes}

[1] See Black Sea Economic Cooperation (Summit Declaration, and Bosphorus Statement). Information on the BSEC is provided on the organization's website: http://www.bsecorganization.org. On the political and security aspects of the BSEC and the Black Sea cooperation, see Pavliuk (1999: 128-150) and Manoli (2003).

[2] See, most recently, Telò, and Guerrieri and Scharrer, with numerous references to current literature on the subject. On BSEC as a case of 'new regionalism', see Tsardanidis (2003).

[3] Emerson and Noutcheva (2004) used the concept of 'gravitation' drawn from the theory of trade.

[4] In fact, the Brussels meeting is positively mentioned in the Report of the Twelfth Meeting of the Council of Ministers of Foreign Affairs of the BSEC Member States, which took place in Komotini, Greece, on 23 April 2005.

[5] Two important EU documents on the ENP are the following: Commission of the European Communities (Wider Europe-Neighbourhood, and European Neighbourhood Policy).

\section{References}

Aydin, M. 'Europe's New Region: The Black Sea in the Wider European Neighbouhood.' Journal of Southeast European and Black Sea Studies 5.2 (2005): 257-283.

Black Sea Economic Cooperation. Summit Declaration on Black Sea Economic Cooperation, Istanbul, 25 June $1992\langle$ http://www.bsec-organization.org $\rangle$.

Black Sea Economic Cooperation. The Bosphorus Statement, Istanbul, 25 June 1992 〈http:// www.bsec-organization.org $\rangle$.

Commission of the European Communities. Regional Co-operation in the Black Sea Area: State of Play, Perspectives for EU Action in Encouraging Its Further Development (COM (97) 597 final), Brussels, 14 November 1997.

Commission of the European Communities. Communication to the Council and the European Parliament. Wider Europe-Neighbourhood: A New Framework for Relations with Our Eastern and Southern Neighbours (COM (2003) 104), Brussels, 11 March 2003.

Commission of the European Communities. Communication to the Council and the European Parliament. European Neighbourhood Policy: Strategy Paper (COM (2004) 373), Brussels, 12 May 2004.

Emerson, M. and G. Noutcheva. Europeanisation as a Gravity Model of Democratisation (Working Document 214), CEPS, Brussels, November 2004.

Guerrieri, P. and I. Falautano. Introduction. Global Governance, Regionalism and the International Economy. Eds P. Guerrieri and H.-P. Scharrer. Baden-Baden: Nomos Verlagsgesellschaft, 2000.

Guerrieri, P. and H. P. Scharrer, eds. Global Governance, Regionalism and the International Economy. Baden-Baden: Nomos Verlagsgesellschaft, 2000.

Lesser, I., S. Larrabee, M. Zanini and K. Vlachos-Dengler. Greece's New Geopolitics. Santa Monica, CA: Rand Corporation, 2001.

Manoli, P. 'The Role of the Black Sea Economic Cooperation (BSEC) in the Stability of the Region.' Paper presented at the Royal College of Defence Studies, Conflict Studies Research Center, 14 October 2003. 
Neugart, F. and T. Schumacher. 'Thinking about the EU's Future Neighbourhood Policy in the Middle East: From the Barcelona Process to a Euro-Middle East Partnership.' Regime Change in Iraq. Eds C.P. Hanelt, G. Luciani and F. Neugart. Florence: RSCAS Press, Florence, 2004, 169-192.

Neugart, F. and T. Schumacher. 'The Geopolitical Implications of the European Neighborhood Policy. European Foreign Affairs Review 10.1 (2005): 1-16.

Pavliuk, O. 'The Black Sea Economic Cooperation: Will Hopes Become Reality?' Subregional Cooperation in the New Europe: Building Security, Prosperity and Solidarity from the Barents to the Black Sea. Ed. A. Cottey. London: MacMillan/St Martin's Press, 1999, 128-150.

Telò, M., ed. European Union and New Regionalism: Regional Actors and Global Governance in a PostHegemonic Era. Aldershot: Ashgate, 2001.

Tsardanidis, C. 'The BSEC: From New Regionalism to Inter-Regionalism.' Paper presented at 'The New European Architecture in the 21st Century. Promoting Regional Co-operation in the Wider Black Sea Area: The BSEC Case,' organized by the International Centre for Black Sea Studies (ICBSS) and the Hellenic Parliament, Athens-Milos, 3-7 September 2003.

Valinakis, Y. The Black Sea Region: Challenges and Opportunities for Europe. (Chaillot Paper 36). Paris: Institute for Security Studies, 1999. 


\title{
Towards a New Model of Comprehensive Regionalism in the Black Sea Area
}

\author{
Sergiu Celac and Panagiota Manoli
}

\begin{abstract}
This article presents an overview of regionalism as is being developed within the framework of the Organization of Black Sea Economic Cooperation (BSEC). It examines the character of BSEC regionalism arguing that significant diversification of its core business (i.e., trade facilitation) towards non-economic issues has occurred since BSEC's conception in 1992. The article further concludes that given BSEC's limitations and its members' priorities, it becomes vital for the future of the Black Sea regionalism that the BSEC develops a structured and constructive relationship with other regional and international actors, particularly the EU, which possesses both the resources and the expertise to move ahead with regional projects. Turning the BSEC into a credible partner with a clear strategy will give a new meaning to the notion of Black Sea regionalism in a united Europe.
\end{abstract}

\section{BSEC: The Institutional Expression of Black Sea Regionalism}

Shortly after the end of the Cold War, regional cooperation emerged as an important means of securing stability, dealing with the problems of economic transition and promoting closer ties with other existing European economic and security structures. The Black Sea Economic Cooperation (BSEC) was established in June 1992 by the governments of eleven states stretching from the Adriatic to the Caspian Seas: Albania, Armenia, Azerbaijan, Bulgaria, Georgia, Greece, Moldova, Romania, Russia, Turkey and Ukraine. In 2004, it witnessed its first enlargement with Serbia and Montenegro joining. The vision behind the launch of the BSEC was to promote economic cooperation in a space that had, for over fifty years, been subject to political, ideological and economic division (for a comprehensive analysis of the BSEC as a regional structure, see Manoli 2004).

Today the BSEC has developed into a relatively mature regional economic organization with a broad and comprehensive institutional basis. It represents the most advanced

Correspondence to: Panagiota Manoli, Director of Studies and Research, International Centre for Black Sea Studies, 4 Xenofontos Street, 10557 Athens, Greece. E-mail: pmanoli@icbss.gr 
expression of regional cooperation in the wider Black Sea area. The highest decisionmaking body is the Council of Ministers of Foreign Affairs (CMFA). A Committee of Senior Officials coordinates current affairs between the CMFA sessions under the guidance of the Chairman-in-Office $(\mathrm{CiO})$ and the assistance of the Permanent International Secretariat (PERMIS) which is based in Istanbul. Agreements, ministerial declarations and sectoral action plans have been adopted in several areas of common interest (e.g., energy, combating organized crime, transport) envisaging joint activities and appropriate coordination mechanisms. The BSEC has consolidated its structures through the activities of permanent and ad hoc working bodies in priority areas of cooperation.

The overall BSEC structure, apart from the intergovernmental dimension, has developed a business dimension (BSEC Business Council), an inter-parliamentary dimension (Parliamentary Assembly of the BSEC, PABSEC), a financial pillar (Black Sea Trade and Development Bank, BSTDB) and a research arm and academic think-tank (International Center for Black Sea Studies, ICBSS). The institutional construction of the BSEC was accompanied by an effort to upgrade its legal and operational foundation in order to respond more effectively to the functional (permanent structures within the BSEC framework) and substantive (areas of cooperation covered by the BSEC) needs of its expanding activities. Consequently, the BSEC identity evolved from a diplomatic conference model into a fully fledged regional economic organization endowed with international legal personality, institutional autonomy and standing organs. The Charter of the Organization of the Black Sea Economic Cooperation was signed at Yalta on 5 June 1998, and entered into force on 1 May 1999 when the informal initiative of the BSEC was transformed into a regional economic organization of the same name. The emergence of the BSEC was an important landmark in the process of regional cooperation, affirming in a solemn way the commitment of the Member States to the vision of further integration through binding legal acts and concrete agreed measures.

The completion of institutional transformation gave the BSEC the necessary means to become a project-oriented endeavour. It is expected that by implementing concrete projects of regional interest and impact, the BSEC will contribute effectively to the prosperity of the people in the region and to the integration of the region's economies with each other and with the European and world marketplaces. An important step forward in the realization of this goal was the establishment by the BSEC, through a unanimous decision, of the BSEC Project Development Fund in 2002. This Fund is financed through voluntary contributions from the BSEC institutional family (states and related bodies) as well as from other sources (third states, financial institutions, international donors, etc.). The aim of the Fund is to facilitate the elaboration and promotion of cooperative projects with a high regional impact from the early stage of a project idea up to pre-feasibility studies leading to access to substantial funding by banks or other financial organizations.

\section{A Comprehensive Type of Regionalism}

Regionalism within the BSEC framework has been from the very beginning comprehensive in nature. In other words, it represents a multidimensional scheme of 
cooperation covering a broad spectrum of activities: trade and investments, energy, transport and communications, environment, tourism, Small-Medium-sized Enterprises (SMEs), combating organized crime and other non-conventional threats, dealing with emergency situations, institutional renewal and improved governance. This comprehensive nature of the BSEC is eloquently expressed in its Economic Agenda, adopted in 2001. It is a political document that outlines the basic fields on which the Member States decided to focus their cooperative engagement.

According to its founding documents, the BSEC cannot be described either as a 'trade bloc' or as a 'security community'. Since its inception, BSEC has been viewed as a tool for achieving the goal of integration into the world economy through a regional approach based on interdependence and natural synergies that could maximize the relative strength of individual countries and thus facilitate their common progress towards prosperity. That is why the BSEC documents underscore the real complementarities that are present in the economies of the participating countries as well as the mutually advantageous character of their expanded economic cooperation.

Another constant feature of the BSEC initiative has been a pan-European vision reflecting also the European expectations of the BSEC participating states. It is not excessive to say that this European commitment has been a strategic goal for the BSEC, highlighted in all official BSEC documents, beginning with the Summit Declaration and the Bosphorus Statement of 1992. The latter contains a very clear statement of the Heads of State and Government stressing that in the building of the new architecture of Europe, their countries and peoples had an important and creative contribution to make and that the Black Sea Economic Cooperation constituted an effort that would facilitate the processes and structures of European integration'. This assessment was confirmed on numerous occasions thereafter, including the adoption in 1999 of a Platform for Cooperation between the BSEC and the EU. It clearly follows that the BSEC endeavour has always had a clear European orientation and been perceived by the participants as a contribution to the evolving new European architecture. Founded on these basic premises, the BSEC gradually consolidated its structures through the activities of permanent and ad hoc Working Groups in priority areas of cooperation. Agreements, Joint Ministerial Declarations and Action Plans have been concluded in several areas of common interest, envisaging joint activities and appropriate coordination mechanisms.

\section{Economic Cooperation as a Declarative Priority}

As envisaged in the BSEC Economic Agenda, the acceleration of effective multilateral economic cooperation and attainment of sustainable development is managed through concerted actions and a project-oriented approach in the fields of: intra-regional trade; banking and finance; energy; transport; communications; environmental protection; science and technology; information technology; education; agricultural development; tourism; SMEs; and exchange of economic information. Throughout the first decade of its operation, the BSEC focused mainly on economic aspects such as the prospects of creating a free trade area. It is to be noted, however, that some significant steps were 
also taken in other, more or less related fields such as cooperation in coping with natural disasters or manmade emergency situations (BSEC, Additional Protocol, 20 October 2005).

Although BSEC was primarily defined as a regional economic organization, it was recognized during the preliminary discussions preceding its establishment that full economic integration would not be an a priori commitment for the participants, even though some concrete steps in that direction could be considered later on. The participating states agreed to promote cooperation by contributing to 'the expansion of their mutual trade in goods and services and ensure or progressively eliminate obstacles of all kinds, in a manner not contravening their obligations towards third parties' (BSEC, Bosphorus Statement, paragraph 14). Their determination to facilitate trade led to a Declaration of Intent for the Establishment of a Free Trade Area in 1997; a plan which was later characterized as 'overambitious' by the BSEC itself, precisely because of existing obligations of some Member States toward third parties or other international organizations. Subsequently, 'trade facilitation and liberalization [was seen] as a more realistic goal for the BSEC Member States at this stage' (BSEC, 'Chart', 2002: 238).

The unimpeded development of trade was originally conceived as a complementary step to the process of national reforms towards market economy. Notwithstanding the repeated statements in that direction, the BSEC partners took few practical steps to liberalize trade amongst themselves and/or to harmonize their policies towards third parties. A number of consultations on cross-border trade facilitation as well as on the reduction of non-tariff impediments to trade took place jointly with the World Trade Organization (WTO) and the United Nations Economic Commission for Europe (UNECE), but they have not produced concrete actions or commitments. The failure to make progress in this area can be explained in part by the fact that some BSEC countries (e.g., Greece, Romania, Bulgaria) were bound by their previously agreed international obligations, particularly vis-à-vis the EU. On the other hand, Azerbaijan refused to consent to deepening economic integration at a sub-regional level prior to the settlement of security issues in the South Caucasus (primarily the Nagorno-Karabakh conflict), while Russia had special commitments in the framework of the Commonwealth of Independent States (CIS) and Eurasian Economic Space. The original plans to establish a free trade area have thus proved unrealistic and obtained limited political support. The draft Recommendation for the Procedure to Eliminate Quantitative Restrictions and Measures with Equivalent Effect on Trade in BSEC Region and Exemplary List of Quantitative Restrictions and Measures with Equivalent Effect on Trade prepared by Turkey in 2001 did not receive active support from the other members, and detailed negotiations on substance never took off.

The lack of consensus among the Member States about the scope and practical modalities of economic cooperation explains only in part why there is a sense of disappointment and frustration about BSEC's failure to deliver on its initial promises. In fact, it should have been clear that the diversity of international commitments (including the fact that not all current BSEC countries are also WTO members) and the adherence by several BSEC countries to EU legislation and rules made the establishment 
of a unified regional economic regime an almost impossible task. To this we may add the fact that weak administrative capacities or regulatory structures for a market economy in a number of countries have obstructed the emergence of a strong regional integrative process.

Over the years, the BSEC Working Group on economic cooperation remained without a plan of action that would set more or less clear and realistic priorities. It has so far met approximately twelve times, which is seldom enough given the primacy placed on the economic character of cooperation. The bulk of its work has been relegated to ad hoc meetings of experts dealing with predominantly technical matters such as investment promotion, avoidance of double taxation and visa facilitation for businessmen. A redirection of priorities from regional trade towards improving the business environment could be witnessed in the meantime. Even in those areas, negotiations had a hard time making progress because of the variety of international jurisdictions (e.g., on visa facilitation where a draft Agreement on Visa Facilitation for Businessmen has been negotiated, but not yet signed).

The same approach applied in the field of investments. The BSEC Member States agreed on the guiding principles, but on a non-binding basis: transparency, nondiscrimination, need for incentives and/or compensation, repatriation of hard currency earnings in anticipation of convertibility, entry and sojourn of key investment actors, elimination of restrictions on the export of capital, code of conduct for investors and settlement of disputes. However, no other action was taken beyond declaratory measures. It was again Turkey that initiated specific measures in the investment domain. In cooperation with the Organization for Economic Cooperation and Development (OECD) and the BSEC Business Council, it designed a concept to promote investments in the BSEC region, which was approved at the meeting of ministers responsible for SMEs in Istanbul on 27 September 2001, and known as the 'Black Sea Investment Initiative' (BSII).

The initial ambition to create a business-led cooperation process was not realized mainly because the private sector remained by and large outside the BSEC decisionmaking process and never took a prominent place as envisaged in the organization's founding documents (Manoli 2005b: 286-288). The representatives of the business community preferred to engage in bilateral contacts and use their own channels of interaction with their counterparts. Moreover, they showed no real inclination to lobby the BSEC in support of their specific interests and plans as it was considered that BSEC lacked the required resources. As a result, BSEC's interest gradually moved away, in practical terms, from trade-related issues.

\section{Diversification by Default Rather Than Design}

In the course of time, the activities of the BSEC branched out into fields that were not envisaged at its conception. One of the most important fields in terms of impact on regional integration and distinct identity has been the wider subject of governance, institutional reform and renewal. This item was included in the Economic Agenda, the major strategy text of the organization, but its serious examination started only in the 
past few years as the link between economic performance and the existence of a proper institutional and regulatory framework has become more evident.

Another crucial topic that surfaced in the BSEC agenda concerns the contribution of the organization toward consolidating security and stability in the region. This subject was brought into focus by the Heads of State or Government in their Istanbul Decennial Summit Declaration of 2002. The International Centre for Black Sea Studies (ICBSS)—which constitutes the official think-tank of BSEC_-was assigned the task of creating and coordinating the work of a special ad hoc Study Group on ways and means of fostering security in the Black Sea region. The ad hoc Study Group, formed of authorized experts from all BSEC Member States, held four brainstorming sessions in Athens (March and July 2003, February and June 2004) and, following two years of negotiations, produced a Background Paper on strengthening security and stability in the region. The Background Paper defines once more security in a comprehensive way; it carefully steers away from direct involvement by BSEC in crisis management and conflict resolution situations, while recognizing that the organization's contribution to the stability in the region is mainly performed by means of enhanced economic cooperation and constructive involvement in dealing with other 'soft' security issues (e.g., organized crime).

On the strength of shared values and perceived common interests, another important new dimension of the BSEC's activities has become its involvement in the management of low-intensity crises, especially those of humanitarian nature caused by natural or manmade disasters, pervasive criminality or serious adverse economic conditions. The BSEC has taken meaningful action on non-traditional security issues such as combating organized crime, terrorism, trafficking in drugs or persons, illegal migration and so on. An intergovernmental Agreement on Cooperation in Combating Crime, in Particular in Its Organized Forms was signed in 1998, and was followed by the adoption of two additional Protocols (3 December 2004, 15 March 2002). Cooperation in this field has been pursued in a satisfactory manner, as illustrated by the establishment of a Network of Liaison Officers from the law enforcement agencies of the BSEC Member States (aimed at providing a speedy regional response to urgent cases and keeping the member countries informed about trans-border crime trends in the region) and the expansion of collaboration in topical areas such as terrorism, trafficking in human beings and illegal migration.

Cooperation in emergency situations has become another field of engagement related to soft security concerns with the signing of an Agreement on Collaboration in Emergency Assistance and Emergency Response to Natural and Man-Made Disasters in April 1998. The Agreement covers cases of extraordinary natural or technological disasters that require a collective response and are beyond the ability of individual states to cope with on their own. Regrettably, the BSEC Member States have not thus far displayed a proactive attitude in the field of emergency assistance and relief despite signing of the Additional Protocol on the implementation of the above-mentioned agreement (20 October 2005). The Agreement itself still does not enjoy the participation of all the BSEC Member States and has been rarely resorted to, although emergency situations justifying the application of the agreement have arisen in the Black Sea region. 
Related in some aspects to the previous themes, but having its own independent dynamics, is the cultural dimension of BSEC cooperation. This dimension has an immense potential for regional interaction since the BSEC region can provide a unique example of constructive dialogue and cooperation among countries with different religious, social and cultural backgrounds.

\section{A Fresh Look at the BSEC Economic Agenda}

The BSEC Economic Agenda of 2001 was an important landmark for the organization. It reaffirmed a comprehensive approach to cooperation by establishing functional links among various facets of regional interaction from environment and infrastructure all the way to social and cultural development or to soft security concerns (e.g., illegal trafficking of drugs and arms, terrorism). Concerted actions for enhanced multilateral economic cooperation were set out as the first aim of the Agenda. Chapters three and four deal with expanded cooperation on soft security matters, democracy building, social and cultural development and education-fields that for the first time since the initiation of BSEC were placed on the list of priorities. The Agenda also includes a specific chapter with reference to the external relations of the BSEC, recognizing that relations with the EU are of central concern. As it appears from the contents of the Agenda, the document is very ambitious, enunciating almost exhaustively every aspect of potential cooperative action in BSEC's internal and external domains. Based on the past experience of relatively modest performance on concrete projects, the central new idea introduced in the Agenda was that of turning the BSEC into a 'project-oriented' organization.

When we take a fresh look at this important document from the perspective of the past five years, we cannot fail to notice a striking imbalance between the professed goals and the envisaged mechanisms for implementation. One of the frequent critical remarks about the Agenda is that it is more of a declaratory nature, a 'wish list' rather than a strategy paper (i.e., setting priorities, providing for implementation mechanisms and for a definite time frame). Some points of the critique are particularly worth mentioning (see, e.g., Adams et al. 2002: 10):

- There is a lack of clarity in defining the priorities of the organization, which is manifest throughout the first ten pages of the document. Its main body includes every possible field of economic action without pointing out a logical sequence of priorities. The fact remains that, when everything is seen as a priority, nothing actually is.

- The commentary on the sectoral policy headings often does not distinguish between national policies and specifically regional projects where BSEC could provide value added and comparative advantage.

- There are no concrete commitments and a timetable of implementation is not included, the Agenda remaining rather a document of general orientation.

- No implementation procedures, financing instruments or follow-up mechanisms are set.

In fact, the only implementation mechanism envisaged in the Agenda is the Project Development Fund (with a very modest budget consisting of voluntary contributions), 
which was established with the aim to finance pre-feasibility studies for projects to be implemented with financing from other international sources. The overall impression from a dispassionate examination of the Agenda is that cooperation in the wider Black Sea region might have been broadened, but it has not deepened. Despite the original concept, it has actually functioned more as a foreign policy instrument rather than a tool for economic cooperation and eventual integration.

\section{Engaging the External Modernizing Anchor}

Given the agreed foreign policy priorities of the BSEC Member States, meeting the development goals set in the founding documents of the organization depends to a high degree on the international dimension of its activities. Once the BSEC's objectives were defined as part of the European integration process, relations with the EU and other European organizations became a central item on the BSEC agenda. Today, the main incentives for reconsidering the fundamentals of BSEC-EU affairs are: the institutional and operational maturity that the BSEC has acquired; the enlargement process of the EU and its implications for the region; and the new quality of bilateral relations between each BSEC Member State and the EU, especially in the post 2004 enlargement period (Manoli 2005a: 167).

The European Commission's European Neighborhood Policy (ENP) Strategy Paper mentions that the ENP will reinforce existing forms of regional and sub-regional cooperation and provide a framework for their further development (2004: 20-21), and it makes explicit reference to the BSEC as such a regional organization. The inclusion of the three sovereign nations of the South Caucasus in the geographical extent of the ENP is a most welcome development and is the first time that the EU has adopted a comprehensive view of its regional policy for the area. The structure and the scope of the ENP, as presented in the Strategy Paper, are congruent with the BSEC goals and agenda of enhancing regional cooperation in the wider Black Sea area as well as promoting a European perspective for the Western New Independent States (WNIS) and the three Caucasian countries. It is also encouraging to see that a separate, consolidated financial instrument was established under the ENP and included in the new financial projections for 2007-2013.

It is our understanding that the BSEC has great potential to serve as a regional conduit for the ENP and other EU schemes, such as the Stabilization and Association Process (SAP) for the Western Balkans, by promoting common priorities and regionwide projects to be included in the proposed individual Joint Action Plans. Specific policy areas like energy, transport, justice and home affairs, institution-building and good governance that are mentioned in the ENP can become the object of joint programmes to benefit from the new financial instrument, in particular when they have a cross-border dimension. Energy and good governance, for example, are areas where the BSEC has already established functional mechanisms for effective multilateral cooperation. Moreover, successful cooperation with the BSEC could have a positive spill-over effect to the other countries included in the ENP or similar sub-regional or bilateral schemes, thus serving as sources of good practice, with a multiplier effect. 
The European Commission prepared, as early as 1997, a policy document in the form of a Communication, providing for the possible establishment of formal institutional links with the BSEC, in which it suggested the following priority objectives that, to a large extent, were shared at the time by the BSEC itself (8-9):

- First, political stability and dialogue, and the strengthening of human rights, democracy and the rule of law.

- Second, the development of the region's transport, energy and telecommunications networks, including connections to European networks.

- Third, regional commercial cooperation and the creation of favourable conditions to attract EU and other foreign investment, including in small- and medium-sized enterprises, while ensuring the compatibility of any new arrangements with existing regimes.

- Fourth, sustainable development, the protection of the region's environmental integrity and nuclear safety.

- Fifth, the reduction of drug trafficking, smuggling and illegal immigration throughout the region.

It took the BSEC two years to respond in the form of the already mentioned Platform of Cooperation between the BSEC and the EU, which apparently was not deemed satisfactory by the EC officials. The question of EU-BSEC institutional links was consequently placed on the back burner for a number of years. It is a fact that, since 1997, while the EU's relations with individual Black Sea countries have seen considerable, though uneven progress, the direct links between the EU and BSEC have stagnated. The reasons for this situation are diverse, but the fact remains that it has hampered the formulation of a BSEC-EU regional partnership.

It has often been repeated that the different status of individual BSEC countries vis$\grave{a}$-vis the EU leads to their inclusion in different programmes and policies implying a diversity of legal and financial instruments. It is our contention that, in the newly prevailing circumstances, the BSEC Member States should be able to make use of the available opportunities through their specific relationships with the EU and its institutions to promote the BSEC's image as a potential locomotive of positive interaction, integration and stability in the Black Sea area and to stress the increasing significance of the Black Sea dimension in existing EU policies. At the same time, they have ample opportunity to promote the Black Sea as a region with its own economic, cultural and, to a certain degree, political identity.

The Black Sea had been disconnected for several decades from the Mediterranean space to which, historically, as Braudel cogently argued, it has always been a 'backyard' or an extension of the Mediterranean (1976: 110). Today, the Black Sea region, thanks to its strategic location and tremendous potential for growth, is given a chance to play a new role in the European system. The time has come, in our judgment, for the EU to develop a Black Sea dimension in its strategic outlook, complementary to and mutually reinforcing of its Mediterranean and Northern dimensions. In line with the decision taken at the BSEC Council in April 2005, and following an extraordinary meeting of the BSEC Committee of Senior Officials with officials from the European Commission on 
11 April 2005, the BSEC is now expected to formulate a new 'Platform for Cooperation between the EU and the BSEC' and define how it views its own role as a regional partner. It has to be stressed that this type of exercise would benefit BSEC in broader terms not just in view of its interaction with the EU, but also with other organizations and with the international community as a whole.

Beyond that strategic approach, which is yet to be developed and duly approved at the BSEC decision-making level, at this stage we may wish to consider some concrete modalities for EU-BSEC interaction. A first step would be for the EU to accept the longstanding offer to acquire official observer status in the BSEC process. This would be in line with the recognition of the BSEC as a regional partner. It would allow the development of direct contacts at executive and technical levels. As mentioned in the BSEC Economic Agenda 'joint meetings of relevant working bodies of the BSEC and the EU as well as conferences, workshops, and seminars of experts in specific fields of common interest would play a useful role in building up new opportunities of productive cooperation between the two organizations' (2001: 28). A second step would be for the EU to incorporate a Black Sea dimension in its strategies and to adjust its present and planned future financial instruments in a way that could facilitate joint programming and implementation of cross-border cooperation.

It stands to reason that BSEC is required to face up to the challenges of the evolving European system and to initiate a comprehensive review of the BSEC-EU relationship resulting in specific recommendations on detailed modalities of cooperation, including:

1. Engaging EU institutions in the work of subsidiary bodies (sectoral ministerial meetings, permanent working groups, ad hoc groups of experts, etc.). The EU's involvement in the subsidiary bodies of BSEC would no doubt enhance the prospects of result-oriented, realistic approaches in the quest for workable solutions in areas of mutual interest. Such an engagement would entail a continuous and, as the case may be, structured dialogue between senior officials and technical experts.

2. Ensure the active, hands-on participation of EU experts (EU Council and European Commission) in the elaboration of a revised version of the 'Platform for Cooperation between the BSEC and the EU', with due consideration of the evolving political landscape and economic social and environmental realities of European integration.

3. Engaging more actively the EU institutions in the work of BSEC Related Bodies (Parliamentary Assembly, Business Council, Black Sea Trade and Development Bank, International Center for Black Sea Studies).

4. Examining in practical terms the possibilities offered through the operation of the BSEC Project Development Fund as an early stage of converting viable project ideas into bankable projects.

5. Reviewing the priority fields of possible EU-BSEC interaction on the basis of accumulated experience in regional cooperation with a view to identifying new synergies of mutual interest and compatible competences.

The interest of the international community towards the BSEC region is not lacking (see Celac 2004: 138-146). Almost all international organizations and major global 
players are, in one way or another, present in the region. This is also manifested in the fact that the United States obtained observer status with the BSEC in 2005. What has been missing, however, is the involvement of the international community, and especially of the EU, in the work of the BSEC. To address this problem, BSEC should come up with its own conceptual contributions and strive to produce some 'success stories' of fruitful cooperation.

\section{Towards a New Pattern of Constructive Regionalism in the Wider Black Sea Area}

One of the frequent criticisms of the Black Sea regionalism has been that it is more about intentions than actual implementation of common projects. Consolidating regional cooperation and making the BSEC a more effective organization would require, to a certain degree, reconsideration of the strategic concept of the organization. The BSEC still lacks a clear sense of realistic priority in its activities. Some of the targets set in the BSEC basic policy documents hardly have a specific regional content. It was rightly noted that 'several domains that do have essential regional substance are left outside the house of BSEC except in a token manner' (Adams et al. 2002: 31-32). This was one of the reasons why the EC has repeatedly insisted that any cooperation with the BSEC should be on a project basis. Responding to that reasonable requirement would actually entail the reconsideration of:

1. The priority objectives set in the BSEC Economic Agenda and the expected political action to be undertaken by the Member States, often entailing legally binding commitments. Developments such as the EU membership of two more BSEC states and the accession of the remaining BSEC states to the WTO may have far-reaching implications for the BSEC-led regionalism, bringing about new challenges, but also totally new opportunities, especially in the field of economic cooperation.

2. The means available to the organization to meet those revised objectives both from additional resources to be earmarked by the Member States from their own budgets for region-wide projects and from wider access to European and international sources of funding.

3. The enhanced political engagement of the BSEC Member States in the implementation of regional Black Sea activities, including a commitment to include an item on the progress of BSEC process in the agenda of cabinet meetings and parliamentary sessions at least once a year.

4. Better coordination among the BSEC Related, Subsidiary and Associated Bodies in order to use more effectively their expertise and human resources for the successful accomplishment of BSEC projects.

5. Enhancing the organizational effectiveness and coordination functions of the BSEC Permanent International Secretariat.

It would appear that the EC and many of the EU Member States share the view that the BSEC should overcome a number of problems before qualifying as a close partner of the EU (a status enjoyed by the Euro-Mediterranean Partnership, the Council of the Baltic States, the Council of Barents/Euro-Arctic Region). It is still true that the BSEC 
region represents a mosaic of problems, containing important potential consequences for Europe in general and for certain European countries in particular. Parts of the wider Black Sea area still raise serious security concerns, especially in relation to the persistent 'frozen' conflicts and pervasive non-conventional threats to regional stability. Before constructive regionalism becomes a reality, it seems that those security dilemmas will need to be addressed in a more effective and forward-looking manner. This is, of course, the primary responsibility of the countries and peoples in the region itself, but the EU and the international community at large cannot lightly dismiss their share of responsibility, nor can they ignore for long their own interest in the continued democratic stability, security and prosperity of the wider Black Sea region. In recent years, despite some setbacks, positive developments have been obvious in the region as stabilization is taking root and good neighborly relations are being steadily, though slowly, developed.

It has to be acknowledged that some objective factors have so far obstructed the deepening of integration processes around the Black Sea. These factors are related both to existing international commitments of the BSEC Member States, especially those facing EU accession, and to local conditions as some of them are either new state entities in the international system and/or are undergoing fundamental restructuring of their national institutions and policy priorities. As the BSEC countries move toward mature statehood and their institutional, legal and administrative structures become more effective in a European sense, we shall expect an increased positive impact on the regional cooperation process. The diversity of the BSEC membership in terms of international affiliation (to EU, NATO, WTO, etc.) should not be seen as a liability, but rather as an asset, probably the most attractive feature of the organization. This diversity will further shape its agenda and the scope of its activities in the future, including its capacity to play a meaningful role in the European and international scene.

Given the limited resources of the BSEC and the magnitude of the problems and challenges that the region faces, it becomes vital for the future of Black Sea regionalism that the BSEC develops a structured and constructive relation with other regional and international actors possessing both the resources and the expertise to move ahead with regional projects. The relationship with the EU is thus critical. Turning the BSEC into a credible partner with a clear strategy will give new meaning to the notion of Black Sea regionalism in a united Europe.

\section{Acknowledgement}

A first draft of this article under the title 'Towards a New Model of Comprehensive Regionalism in the Wider Black Sea Area' was presented at the conference 'The Black Sea Region: Towards a Partnership for the 21st Century', organized by the Friedricht Ebert Foundation in Constanta, Romania, on 10-11 June 2005.

\section{References}

Adams, T. et al. Europe's Black Sea Dimension. Brussells and Athens: CEPS and ICBSS, 2002. Black Sea Economic Cooperation (BSEC). Bosphorus Statement. Istanbul, 25 June 1992. 
Black Sea Economic Cooperation (BSEC). Declaration of Intent for the Establishment of a Free Trade Area, 1997.

Black Sea Economic Cooperation (BSEC). Agreement on Collaboration in Emergency Assistance and Emergency Response to Natural and Man-Made Disasters, April 1998.

Black Sea Economic Cooperation (BSEC). Agreement on Cooperation in Combating Crime, in Particular in Its Organized Forms, 1998.

Black Sea Economic Cooperation (BSEC). Platform for Cooperation between the BSEC and the EU. Tbilisi, 20 April 1999.

Black Sea Economic Cooperation (BSEC). Economic Agenda for the Future towards a More Consolidated, Effective and Viable BSEC Partnership. Istanbul: BSEC PERMIS and ICBSS, October 2001.

Black Sea Economic Cooperation (BSEC). Black Sea Investment Initiative (BSII) (approved Istanbul, 27 September 2001).

Black Sea Economic Cooperation (BSEC). 'Chart of the Implementation of the BSEC Economic Agenda'. In BSEC PERMIS. Handbook of Documents, vol. 5. Istanbul, April 2002. 123-249.

Black Sea Economic Cooperation (BSEC). Additional Protocol to the Agreement among the Governments of the Black Sea Economic Cooperation Participating States on Cooperation in Combating Crime, in Particular in Its Organized Forms (Kyiv, 15 March 2002).

Black Sea Economic Cooperation (BSEC). Background Paper on the Ways and Means of Enhancing the BSEC Contributions to Strengthening Security and Stability in the Region.

Black Sea Economic Cooperation (BSEC). Additional Protocol on Combating Terrorism to the Agreement among the Governments of the Black Sea Economic Cooperation Participating States on Cooperation in Combating Crime, in Particular in Its Organized Forms (Athens, 3 December 2004).

Black Sea Economic Cooperation (BSEC). Additional Protocol to the Agreement among the Governments of the Participating States of the Black Sea Economic Cooperation (BSEC) on Collaboration in Emergency Assistance and Emergency Response to Natural and Manmade Disasters (Kyiv, 20 October 2005).

Braudel, F. The Mediterranean and the Mediterranean World in the Age of Philip II. London: Fontana/ Collins, 1976.

Celac, S. 'Five Reasons Why the West Should Become More Involved in the Black Sea Region'. A New Euro-Atlantic Strategy for the Black Sea Region. Eds R. Asmus, K. Dimitrov and J. Forbrig. Washington: The German Marshall Fund, 2004. 138-146.

European Commission. 'Regional Cooperation in the Black Sea area: State of Play, Perspectives for EU Action Encouraging its Further Development', COM(97) 597 Final. Brussells, 14 November 1997.

European Commission. Communication from the commission. European Neighbourhood Policy: Strategy Paper (COM (2004) 373). Brussels, 12 May 2004.

Manoli, P. The Formation of Black Sea Economic Cooperation: A case study of subregionalism, thesis. Coventry: University of Warwick, April 2004.

Manoli, P. 'Bringing the Black Sea Economic Cooperation and the European Union Closer'. Southeast European and Black Sea Studies. (2005a): 167-169.

Manoli, P. 'Limiting Integration: Transnational Exchanges and Demands in the BSEC Area'. Agora Without Frontiers. Athens: Institute of International Economic Relations, 2005b. 268-291. 


\title{
Turkish-Russian Relations: The Challenges of Reconciling Geopolitical Competition with Economic Partnership
}

\author{
DUYGU BAZOĞLU SEZER
}

\begin{abstract}
Turkey and Russia, regional powers that have traditionally belonged to two opposing continental systems, have been undergoing "teuctonic" change since the late $1980 \mathrm{~s}$. Their relations over the past decade have been marked by a combination of cooperation and competition. Unprecedented levels of economic cooperation have fostered a new climate of interdependence between Turkey and Russia, perhaps even exerting a moderating influence on their geopolitical competition in Eurasia. But, the hardening of Russia's approach in 1999 to Chechnya, and to the West in general, does not appear to be a good omen for the future of Turkish-Russian relations.
\end{abstract}

The multiple issues, complexities, and contradictions of Turkish-Russian relations in the 1990s offer a microcosm of some of the outstanding new global forces that have shaped the post-Cold War international order. Globalization, the diffusion of power from the center to the periphery, the proliferation of regional conflicts, the wave of Western messianism to spread democracy and human rights, and the growing international demand for fossil fuels as a primary source of energy are all examples of trends that have affected - and been affected by - Turkish-Russian relations.

Relations between neighboring countries are generally expected to alternate between conflict and cooperation. But the salience of Turkish-Russian relations flows from the fact that the two states are major regional powers - Russia, after all, was a superpower until the late 1980s and still boasts a massive nuclear arsenal - situated at the crossroads of two formerly adversarial continental systems, the Trans-Atlantic and the Eurasian.

Russia was in full control of the Eurasian system - seat of its empire until 1991. However much diminished and despite the growing influence of the United States, Russia remains the preeminent power in Eurasia. ${ }^{1}$ While it has established formal relations with the Trans-Atlantic system through the North Atlantic Treaty Organization (NATO)-Russia Founding 
Act of 1997, Moscow nevertheless strongly resists a greater regional role for external actors, in particular the Trans-Atlantic powers.

Turkey has been a member of the Trans-Atlantic system, comprising the eastern-most end of its southern region, since Ottoman times. Moreover, it is the only member of this strategic system that is directly tied to certain subregions of Eurasia - Central Asia, the southern Caucasus, and the northern Black Sea - through geography, history, language, and culture. The erosion of Soviet control over the borderlands since the early 1990s has given way to a powerful new Turkish interest in Central Asia and the southern Caucasus, posing a potential challenge to Moscow's traditional influence and interests in Eurasia. ${ }^{2}$ The extent of this challenge has been magnified in Russian eyes because Turkey remains the only direct physical and political connecting link between the TransAtlantic system - which Moscow still does not entirely trust - and the Eurasian system where it has been on a strategic retreat.

Thus, the scope of Turkish-Russian relations is broader than the term "bilateral" would routinely suggest. While many of the issues in Turkish-Russian relations have bilateral content and coloring - mutual recriminations of supporting separatist terrorism in order to undermine each other's territorial integrity - they have been influenced by the core issues that have dominated the agenda of Trans-Atlantic and Eurasian interaction in the 1990s. The controversy over Russia's violation of the force restrictions in the north Caucasus stipulated in the 1990 Conventional Forces in Europe (CFE) treaty is perhaps the best example of the connection between Turkish-Russian bilateral relations and developments in the Trans-Atlantic and Eurasian worlds in the 1990s.

The negative repercussions of the wars in Bosnia (1992-95) and Kosovo (early 1999) for Turkish-Russian relations, where the countries sided with opposing parties, also show how bilateral relations cannot be isolated from broader developments. True to historical and Cold War traditions, in the 1990s Turkish and Russian policies have largely stood far apart in regions where both claim to have important interests, namely the southern Caucasus, the Middle East, and the Balkans. Russia has also shown outright support for Turkey's antagonists, the Greek-Cypriots, in the Cyprus issue.

The considerable chasm in Turkish and Russian regional approaches thus injects an inherent structural weakness or burden on bilateral relations. The Russian sale of S-300 air-defense systems to the Greek- 
Cypriot government caused serious tension in bilateral relations until the Greek-Cypriot government decided in December 1998 not to proceed with deployment. On the Russian side, the intensification of Turkish-Israeli relations since 1996, in particular in the military field, has caused consternation because of its presumable adverse impact on the regional balance to the disadvantage of Moscow and its Arab and Iranian allies.

If external developments are one profound influence on Turkish-Russian relations, pressures for domestic systemic change are another. For example, the levels of bilateral trade achieved by the mid1990s can primarily be explained, from the Russian perspective, by the urgent demand of an economy in transition for investment capital and consumer goods, and from the Turkish perspective, by the increasing ambitions of the Turkish business community to integrate into the world economy in order to find new markets for their goods and services.

\section{A History of Russian-Turkish Relations}

The glue that binds the regional and domestic factors shaping Turkish-Russian relations is history. Turks and Russians have lived side by side for several centuries and their encounters were often dominated by rivalry and war. The conquest of Constantinople in 1453 is the seminal event that set the stage for the future course of bilateral relations. After that momentous event, the Russian and the Ottoman empires, representing two different civilizations - Slavic/Orthodox and Turkish/Islamic, respectively - engaged in what eventually evolved into incessant, fierce confrontation in Eastern Europe and the Caucasus. ${ }^{3}$

The age of imperial competition that ended with World War I was followed by an extraordinary period of mutual empathy and accommodation between the leaderships of two young states, Lenin's Bolshevik regime in Moscow and Mustafa Kemal's nationalist regime in Ankara. ${ }^{4}$ The Turkish-Russian "spring" was short-lived, however, and relations had cooled by the end of the next decade. At the end of World War II, the Soviets pressed for joint control of the Turkish Straits and territorial concessions in Turkey's northeast. Turkey then sought security in a military alliance with the United States, a move that culminated in NATO membership in 1952, and the two countries remained ideological and military adversaries throughout the Cold War. ${ }^{5}$ 
The long history of Turkish-Russian relations is not one of positive images nor does it inspire bright hopes for the future. On the contrary, that same history has nourished negative perceptions that have been passed on from one generation to the other. When such memories survive, both at the official and popular levels, they can be expected to influence state policy.

Two historical episodes have carved especially sharp and enduring impressions on respective national consciousness. The first is the powerful, perhaps decisive, role played by Russia in the dismantling of Ottoman rule in the Balkans by acting as the patron-liberator of Balkan peoples, most importantly of Greeks and Serbs. The other concerns Russian perceptions of Turkey's relationship with peoples of Turkic origin inside the former Soviet empire. The multinational USSR was basically a Slavic-Turkic empire, as the Turkic peoples were the second largest group after the Slavs. Russia, by and large, had managed to seal its border against the nationalism that swept Europe and the Ottoman empire in the nineteenth century. Thus, even timid signs of a nationalist awakening among Russia's Turkic/Muslims in the early twentieth century were sufficient to alarm Moscow. The activities of Enver Paşa - the Ottomans' last minister of war whose pro-German leanings are generally blamed for the empire's fall - in Turkistan in 1920 and 1921, aiming to unite all Turkic peoples within a single political entity, appear to have engendered among the Russians a lasting mistrust about Turkish aspirations with respect to Russian Muslims. According to many Russian observers, Turkey has in the past, and is presently, pursuing "pan-Turkism."

\section{How to Characterize Turkish-Russian Relations in the 1990s}

The evolution of relations between historical rivals Russia and Turkey can best be captured by the term "virtual rapprochement." Virtual rapprochement refers to a state of bilateral relations in which public manifestations of state-level adversity and hostility have nearly completely disappeared; the importance of cooperation in a range of fields for furthering respective national interests is mutually perceived and publicly articulated; governments desist from using inflammatory rhetoric so as not to arouse public hostility; and officials keep the lines of communication open in order to safeguard relations against the impact of sudden crisis. On the other hand, a hard kernel of mutual fear, mistrust, and suspicion remains in the minds of the decisionmakers and political elites. 
The scope of Turkish-Russian relations has been broadened as well as deepened in the 1990s, but the entire range of possibilities for friendship and cooperation have not been exhausted primarily because of residual mutual fear and mistrust. The level of relations reached in the 1990s ascends above routine "normalization" but falls several steps short of genuine rapprochement.

\section{Managed Geopolitical Competition}

The process of moving towards virtual rapprochement has been underpinned by two major but diametrically opposed dynamics: managed geopolitical rivalry and unique economic cooperation verging on interdependence. Managed competition represents Russia's and Turkey's mutual evaluations of each other as geopolitical competitors, in particular with respect to their role and influence in the southern part of the new Eurasia, also called the southern Newly Independent States (NIS). In policy terms this mindset has led to behavior - some of it well thought out but most of it reactive - aimed at constraining as much as possible the other's freedom of movement and long-term influence in the region. A corollary to competition was the desire to exclude the competitor.

The exclusion of external powers from the former Soviet space was one of Russia's main objectives as it sought to turn the Commonwealth of Independent States (CIS) into a genuine vehicle for reintegration among the former Soviet republics - an objective not even close to realization at the end of the decade. This Russian strategy especially affected Turkey due to its special ties to the southern Caucasus and Central Asian republics. ${ }^{9}$

Turkish policies in the new Eurasia were equally exclusionary, especially early in the decade. They were designed to serve two mutually reinforcing functions: to assist the southern NIS in solidifying their newly won independence, especially by facilitating their integration into the international community, and second, to weave special bonds among Turkey, Azerbaijan, and the Turkic republics on the basis of common ethnic, linguistic, and cultural roots. ${ }^{10}$

If realized, Turkish objectives would contribute, however indirectly, to a weakening of Russia's influence in southern Eurasia while enhancing that of Turkey. Turkey possibly entertained considerable pan-Turkic aspirations in the early post-Soviet world, but soon discovered that pan- 
Turkism was not on the immediate agendas of the newly independent Turkic nations. The coup d'état against President Abulfaz Elchibey in Baku in the summer of 1993 was perhaps the turning point ending Turkey's hopes to erect a community of Turkic nations using the southern NIS as a potential rallying forum. Turkey henceforth embraced a less sentimental but more pragmatic and state-to-state type approach.

\section{A Checklist of Controversies and Disagreements}

A long list of publicly articulated issues and privately entertained concerns have strained relations between the two countries. They include:

- Mutual recriminations of support for ethnic separatism, with Russia charging Turkey of assisting Chechnya and Turkey accusing Russia of aiding Kurdish separatism and PKK terrorism;

- The competition over Caspian Sea oil pipelines, with Russia pressing for the Baku-Novorossiisk pipeline and Turkey for the Baku-Ceyhan pipeline;

- The Turkish sense of encirclement by Russian military bases in Georgia and Armenia;

- The implicit tension in their respective approaches to conflict resolution and peacekeeping in southern Eurasia, with Russia intent on keeping these functions primarily, if not solely, within the jurisdiction of the CIS, and Turkey advocating a role for the international community in general and for Nagorno-Karabakh in particular, a position in line with the Karabakh-related decision of the Organization for Security and Cooperation in Europe (OSCE) at the Budapest Summit in 1994;

- Russian apprehensions over perceived Turkish naval superiority in the Black Sea at a time when the former Soviet Black Sea fleet is much weakened;

- Turkish discomfort with the Russian view of Iran as a counterweight to Turkey in the south Caucasus and Central Asia;

- The destabilizing nature, from the Turkish perspective, of Russian arms exports policies in the region, in particular the sale of S-300 air defense missiles to the Greek-Cypriot government in Nicosia. 
Russian assistance to Iran's nuclear program is also most troubling to Ankara;

- Russian objections to Turkish policy since 1994 to regulate the traffic of vessels in the Turkish Straits for environmental and safety reasons in view of the prospect of greatly increased tanker traffic carrying Caspian Sea oil to world markets;

- Surprisingly, perhaps, one important discord was resolved in early 1999 through bilateral accommodation, namely the disagreement over the so-called "flank" issue on the modernization of the 1990 CFE treaty. Russia once again exceeded the limited amount of equipment the treaty allows in the north Caucasus during the second Chechen war, raging since September 1999. In the face of strong Western criticism, Russia verbally pledged to honor its treaty commitment and the modernized CFE text was adopted at the OSCE's Istanbul summit of November 19-20, 1999.

Why this long list of controversies, disagreements, and disputes? Almost without exception, they are all a manifestation of the competition in southern Eurasia galvanized by the disintegration of the former Soviet Union.

\section{Mechanisms for Managing Competition and Controversy}

Diplomatic communication and regular political contacts among senior officials were Turkey's and Russia's primary instruments of managing their unarticulated yet genuine competition. On at least one occasion, however, in April 1992, Russia resorted to explicit nuclear intimidation to deter Turkey - when Marshal Yevgenii Shaposhnikov, then commander-in-chief of the CIS armed forces, warned of "a Third World War" if Turkey intervened in the Armenian-Azerbaijani war to help Azerbaijani forces. ${ }^{12}$

High-level exchanges between Turkish and Russian officials throughout the 1990s laid the ground rules and political commitments for improved cooperation. The joint statements issued at such meetings not only carried messages of reassurance to their respective publics but also played up the potential for intensified partnership. In fact, Turkish governments in the mid-1990s toyed with the notion of a deeper partnership with Russia as a possible alternative to the country's deteriorating relations with Europe. Ankara froze political dialogue with 
the European Union (EU) following the latter's effective rejection of Turkey's candidacy for eventual membership at the Luxembourg Summit of December 12, 1997. The search for new directions for Turkish foreign policy intensified during this period, but neither Russia nor any other state has yet emerged as a real alternative. ${ }^{13}$

Three visits are of special significance: Prime Minister Süleyman Demirel's visit to Moscow in May 1992, Prime Minister Viktor Chernomyrdin's trip to Ankara in December 1997, and Prime Minister Bülent Ecevit's visit to Moscow in November 1999.

Demirel's visit took place in the shadow of Azerbaijan's military defeat after the Armenian advance of April 1992 and Marshal Shaposhnikov's subsequent warning of nuclear retaliation if Turkey intervened. Nevertheless, the Treaty of Friendship and Cooperation signed during Demirel's visit declared that the two countries would base their relations on good neighborliness, cooperation, and mutual trust. ${ }^{1+}$ This is the most farreaching document signed between the two states that aims to steer the spirit and direction of Turkish-Russian relations on a positive course.

Prime Minister Viktor Chernomyrdin's visit to Turkey on December 16-17, 1997 was the first in the post-Soviet period by a head of Russia's government. Its main objective was to close a huge natural gas deal called the Blue Stream. The $\$ 30$ billion, 25-year project envisaged Russia supplying 16 billion cubic meters of natural gas a year to Turkey by the year 2010 through underwater pipelines in the Black Sea. ${ }^{15}$ On that occasion Turkish prime minister Mesut Yilmaz expressed the Turkish desire to discuss any question and to cooperate rather than compete with its great neighbor. ${ }^{16}$ Chernomyrdin, for his part, declared that: "If Turkey shakes the hand extended by Russia, we shall become strategic partners in the economy in the twenty-first century ... We shall be able to do much together in third countries and contribute to the insurance of stability and tranquillity in the region." 17

Ecevit's November 1999 visit was perhaps the most controversial domestically. It took place at a time when Russia's military offensive against Chechnya, escalating since September, raised powerful foreign objections, including objections from Turkey. The opposition in the Turkish parliament led by the Islamist Virtue Party denounced the visit and asked the prime minister not to proceed with it. ${ }^{1 \times}$

Ecevit's decision to go ahead with the visit demonstrated the importance he attached to upgrading the relationship with Russia at the 
risk of alienating the country's estimated 5-6 million citizens of Caucasian origin, and disappointing the Chechens and the regions' other Muslim nationalities who have traditionally seen Turkey as a friend. Before the visit, Ecevit described Chechnya as "an internal problem of Russia." 19 He underlined the point that Turkey believes in the importance of the territorial integrity of Russia as it does in its own. The prime minister also pointed to Turkey's deep humanitarian concerns over the tragedy, especially concerning civilians and refugees. The main items on the agenda of the Ecevit visit concerned cooperation against international terrorism, the completion of technical formalities relating to the Blue Stream, and the reinvigoration of economic relations.

The joint statement denouncing terrorism in general terms was the only concrete achievement of the Moscow talks. ${ }^{20}$ In an interview with the press, Prime Minister Vladimir Putin said: "We denounce international terrorism and express our common intention to fight this evil, which affected many countries. We denounce terrorism in all its manifestation. Russia has never supported and will never support any terrorist aspirations directed against Turkey, no matter where they come from.".1

Much to the consternation of Turkish democrats, Islamists, and nationalists, Ecevit clearly had assigned higher priority to accommodating Russia in order to constrain Russia's support for the PKK over diplomatically confronting Moscow in order to induce a political resolution of the Chechen crisis without further loss of Chechen life. ${ }^{22}$

The whole matter of equating the Chechnya and PKK-Kurdish questions is very complex. For Moscow and Ankara, the Chechen and Kurdish movements pose a threat to each country's territorial integrity, respectively. Their significance for bilateral relations and regional politics has been dramatically magnified, however, by the opening of fossil fuels from the Caspian to world markets in the post-Soviet era. Chechnya and eastern Turkey, where a large portion of Turkish Kurds live, offer attractive pipeline routes for the transport of Caspian oil. Thus, the geopolitical and economic stakes of stability, and conversely the costs of instability, in Chechnya and eastern Turkey are extremely high.

The Russian press gives wide coverage to Moscow supporters of the PKK, which is formally recognized by Western nations as a terrorist organization. The Duma in general, and the Duma Committee for Geopolitics in particular, has been the backbone of support within the open system. ${ }^{23}$ In contrast, the government publicly distances itself from 
links with, and responsibility for, the PKK's numerous activities inside Russia. In the winter of 1998-99, President Boris Yeltsin and Prime Minister Yevgeny Primakov saved Turkish--Russian relations from diplomatic disaster when they refused to grant asylum to PKK leader Abdullah Öcalan, as requested by members of the Duma, and pressed for his deportation from the country. ${ }^{24}$

The second Chechen war starting in September 1999 rekindled the inherent potential for Turkish-Russian tension regarding developments in the Caucasus, even if Turkey adopted a clear policy of non-involvement in Russia's "internal affair," displaying carefully controlled frustration with the tragic humanitarian dimension of the conflict. In contrast, previous Turkish governments, especially those led by Tansu Çiller, the leader of the center-right True Path Party, had taken a decidedly more assertive stance during the first Russo-Chechen war on securing Moscow's approval for Turkish humanitarian aid to Chechnya.

Despite the Turkish government's controlled reaction, a new wave of hostility aimed at Turkey has reappeared in Russia. Among the numerous scenarios discussed in the Russian press on the future of Turkey's role in the Caucasus, writer Alexander Solzhenytsin's September 15, 1999 article in Argumenti Fakti predicting "the possible accession of Chechnya to the Turkish empire after battling through Georgia," stood out. ${ }^{25}$ The political opposition in Turkey and even members of the coalition government - the nationalists - leveled sharp criticism at the prime minister, as previously mentioned and the media gave extensive coverage to the humanitarian disaster caused by the Russian military campaign.

\section{The Caucasus: The Focal Point of the Rivalry}

The Caucasus is generally recognized as the focal point of TurkishRussian regional rivalry. This region has traditionally been perceived in Russia in terms of vital security and economic interests. Russia's retrenchment from the southern Caucasus in 1991 was received as a devastating blow to the security of the federation, giving rise to a powerful "security vacuum syndrome" among the political elite, "lest other powers - whether regional players like Turkey and Iran, or global ones like the United States - should fill it, to the detriment of Russia's own interests." ${ }^{26}$

A prominent military analyst, Pavel Felgengauer, links the strategic significance of the southern Caucasus for Russian security not simply to 
Turkey's presumable aspirations, but implicitly to Turkey's position as a NATO member: "The southern Caucasus is Russia's main strategic forward defense area directly affecting the military situation in the NCMD (North Caucasus Military District). Many Russian forces still remain in the Trans-Caucasus, deployed on the old strategic frontier on the border with Turkey [emphasis mine], a NATO member." ${ }^{27}$

The disintegration of the federation as a result of pervasive ethnic unrest and separatism in the north Caucasus and Turkey's presumable aspirations to facilitate this process, is one of the most feared scenarios, as suggested for example by Chairman of the Federation Council (the upper house of the Russian parliament) Yegor Stroyev when, during a visit to the region in January 1998, he expressed: "Categorical disagreement with the political itch among some officials to establish a Confederation of transCaucasian Peoples including Turkey, Chechnya, and probably other republics of the North Caucasus."28

Similarly, in a veiled allusion to Turkey, Vyacheslav Mikhaylov, the acting minister for nationalities and federal relations, said at a press briefing on April 8, 1998 that ".. a serious struggle for the creation of a single Caucasus but without Russia, is currently under way ... all problems of Russian federalism are put to the test precisely in the North Caucasian region." 29

Turks feel that they too have deep-rooted cultural, ethnic, linguistic, and economic interests in the southern rim of the New Eurasia. Turkish interests in the southern Caucasus enjoy the priority of place, followed by Central Asia and the Black Sea. Thus, there is a fundamental conflict of interest between Turkey and Russia, as their respective interests in these regions seem to be perceived as mutually exclusive.

Turkish influence in the southern NIS operates through the implementation of policies designed to serve, first and foremost, the strategic objective of the consolidation of these countries' independence, as previously explained. The consolidation of independence in effect means a state of affairs that will ensure the irreversibility of the postimperial status quo, fortifying the NIS against possible future neoimperialist influences and projects sponsored by Moscow. In the first half of the 1990s, when Moscow adopted an openly assertive policy in the "near abroad" through the CIS, at the same time that it insisted on the socalled Monrovsky doctrine, Turkey, like many quarters in the West, was very nervous. In a major speech before the Turkish Grand National 
Assembly on September 1, 1993, at the beginning of the parliamentary year, President Süleyman Demirel questioned if Russia was behind the local conflicts in the NIS as part of a strategy to reconstruct the Soviet empire.

Logically, therefore, there is tension in Turkish and Russian interests in this part of the world, basically because of their competing visions of the future order in the new Eurasia. The Turkish vision in essence foresees a liberal, pluralistic new Eurasia no longer dominated by Moscow. The Russian vision, in contrast, seeks the reintegration of the same space under Moscow's leadership, if not control.

The balance sheet between these two visions seems to favor Turkey, though mainly due to forces beyond Turkey's control. But, certainly Turkey's almost unflinching political and moral support to the southern NIS was a profound source of strength especially in the early post-Soviet years when these states got their first taste of independence.

\section{The Shifting Loyalties of the Local Powers}

Among all the southern NIS, Azerbaijan has traditionally held a unique place in Turkish perceptions and policies. A brief cooling-off of relations between Ankara and Baku followed the 1993 coup d'état which brought Heydar Aliyev to power.

Regional realpolitik seems to have eventually persuaded the Azeri leadership to shed the "Turkey, the new Big Brother" complex. Since roughly the mid-1990s, political and security relations between the two countries have been robust. Turkish military assistance to Azerbaijan in the form of training and equipment deliveries is a well-known secret. More significant are recent calls by Baku to host Turkish, U.S., or NATO military bases as a hedge against the threat posed by Russian arms deliveries to Armenia - an appeal as yet not answered by any of the parties. ${ }^{30}$ In relative terms, economic relations with Azerbaijan have trailed behind.

Georgia has also moved closer to Turkey. High-level exchanges of visits by civilian and military authorities, as well as summits among Presidents Süleyman Demirel of Turkey, Edvard Shevardnadze of Georgia, and Heydar Aliyev of Azerbaijan have become a routine exercise. Equally important is the fact that Turkey has replaced Russia as Georgia's main trading partner. ${ }^{31}$

What is more novel in the southern Caucasus' new military landscape is the intensification of direct Turkish military cooperation with Georgia. 
In 1998 , Ankara contributed $\$ 5.5$ million to the modernization of the Georgian army. Agreements were reached in the summer of 1999 for additional grants of $\$ 1.7$ million and $\$ 3.7$ million. ${ }^{32}$

The most significant aspect of the evolving security perceptions and alignments in the southern Caucasus is the pro-NATO leanings of Azerbaijan and Georgia, both of which signed Partnership for Peace (PFP) agreements with the defense organization. They both view NATO as potentially the most stabilizing force in their turbulent region. Former NATO Secretary General Javier Solana paid two visits to the region in 1997 and 1998, demonstrating Brussels's commitment to stability in the region.

Publicly gravitating toward Turkey, the United States, and NATO over the last few years is part of Azerbaijan's and Georgia's broader objective of reducing their dependence on Moscow. Both countries continue to suffer from separatist challenges to their territorial integrity and generally see Moscow as an agent of destabilization aiming to sustain its former hegemony.

Azerbaijan is the only CIS member that, from independence, has refused to allow Russian troops on its soil. ${ }^{33}$ In contrast, Georgia hosts three Russian military bases containing some 8,000 Russian regular troops, as well as a few artillery deployments in Abkhasia where one Russian infantry battalion serves as part of a UN peacekeeping force..$^{34}$ Since 1997, Georgia has been negotiating with Moscow over the withdrawal of Russian border guards from Abkhasia. Moreover, when the CIS Collective Security Treaty came up for renewal in May 1999, both Georgia and Azerbaijan opted out. ${ }^{35}$

Armenia's situation is altogether different. Viewing Turkey and Azerbaijan as the most important security threats, Yerevan looks to Russia as the primary guarantor of Armenia's security. A firm mutual defense agreement binds the two countries. Two Russian military bases sit within Armenia, roughly eight kilometers from the Turkish border, and in 1999, plans were underway for the modernizing the bases with Russian S-300 air defense systems. ${ }^{36}$ Russian border troops continue to patrol the Turkish-Armenian and Turkish-Georgian borders.

The explosion of separatist conflicts in the Caucasus in the 1990s has given Russia almost a free hand in manipulating local weaknesses to its advantage. It has flexed significant military muscle by concluding defense agreements with Georgia and Armenia and by claiming a monopoly role 
for the CIS - effectively meaning Russia - for peacekeeping operations within CIS boundaries. ${ }^{37}$ The Russo-Chechen war of the 1994-96 period, in particular, convinced the Russian leadership to bolster its forces in the region in excess of the numbers stipulated in the $1990 \mathrm{CFE}$ treaty. ${ }^{38}$

A return to hostilities in Chechnya in September 1999 and the murder of Prime Minister Yazgan Sargisian and seven Armenian parliamentarians by terrorists on October 27, 1999, have thrown the Caucasus into a new stage of extreme instability. Among other things, the bloodbath in Armenia's parliament is almost certain to indefinitely delay an ArmenianAzerbaijani peace. ${ }^{39}$

In short, Russia's strategic approach to the southern Caucasus indicates a basic mistrust of Turkey, to say nothing of its NATO allies. The same policies feed into a vicious security dynamic, reinforcing Turkish fears of Russia. Turkey has been seriously troubled by Russia's post-1991 military presence in neighboring Georgia and Armenia and its continued violations of the CFE limits.

\section{The Race Over Caspian Basin Pipelines}

The competition over the Main Energy Pipeline (MEP) to deliver oil from the Caspian Sea basin to the West is perhaps the most visible example of the geopolitical competition between Russia and Turkey. Briefly stated, Russia insists on the Baku-Novorossisk pipeline and Turkey on the Baku-Ceyhan line to serve as the MEP for Azerbaijani oil. ${ }^{40}$ Clearly, the choice of either alternative would dramatically bolster the winner's regional and international clout while diminishing that of the loser.

The race over the MEP by far exceeds the boundaries of bilateral relations. It is truly the new "Great Game." The United States' more visible and committed stance regarding peace and stability in southern Eurasia since 1997 has bolstered Turkey's position; American support for the Baku-Ceyhan route has been constant. However, the final decision rests with the AIOC (Azerbaijani International Operating Company), the consortium of leading international and national oil companies which in 1994 was awarded the right to prospect, develop, and export Azeri oil in several off-shore sites in the Caspian Sea.

The controversy over the MEP has exacerbated regional instabilities. Instability in the north Caucasus, most notably in Chechnya and Dagestan, seems to be closely connected to the pipeline issue as the Russian proposed line passes through both provinces. The October 1999 killings in 
the Armenian parliament might also be linked to the pipeline debate. The Kurdish issue also forms part of the energy knot, as the Turkish alternative passes through southeastern Turkey, a hotbed of PKK guerilla war since 1984. Some Duma deputies have used this fact to argue against a Baku-Ceyhan line.

\section{Economic Cooperation: Exemplary by Historical and Regional Standards}

Standing in stark contrast to the bumpy, often controversial, Turkish-Russian political relations is the dynamism of economic relations between the two countries. Cooperation, rather than competition, has dominated the economic sphere, and has been generally pursued with resolute political will on both sides. Economic relations have recorded unprecedented levels, historically and by regional standards, in the postSoviet era. The spectrum of transactions has also been quite diverse. Foreign trade, both official and unofficial, tourism, and retail business and construction activity by the Turkish business community sustained peak levels for several years in the mid-1990s.

Bilateral economic relations fall under two general headings: trade and services. Trade between Turkey and Russia increased several fold since the final days of the Soviet Union, reaching \$8-10 billion annually until Russia's financial crash in August 1998. Official trade accounted for $\$ 3.5$ billion of this figure in 1998, with Turkish exports to Russia worth $\$ 1.347$ billion and imports worth $\$ 2.152$ billion. ${ }^{41}$ These figures represent a 34.4 percent drop in Turkish exports in 1997 which stood at $\$ 2.056$ billion, and a 0.1 percent decline in imports which stood at $\$ 2.174$ billion. ${ }^{42}$

The balance in 1998 trade figures is made up of unofficial trade, also called "shuttle trade," which refers to merchandise that Russian shoppers in Turkey take home with them. Because of its informal nature, hard statistics on unofficial trade are not available but estimates put the annual volume of shuttle trade in the 1991-96 period at \$6-10 billion. This lucrative trade, however, had been on a downward trend even before the 1998 Russian financial crisis and it is generally estimated that 1999 shuttle trade shrunk to one-third of its previous volume.

Russian natural gas has formed the biggest single item in Turkish-Russian trade since 1987, when initial deliveries by Russia began. Currently, Russia delivers 14 billion cubic meters (bcm) of gas 
annually to Turkey. The Blue Stream project negotiated in December 1997 is expected to increase the annual volume to 30 billion by the year 2010 , with smaller deliveries scheduled to begin in the year 2000 upon the completion of an underwater pipeline through the Black Sea. ${ }^{43}$

The revitalization of economic relations was a primary objective of Ecevit's visit to Moscow in early November 1999. One of four technical agreements concluded during the visit relates to upgrading the activities of the Joint Economic Commission charged with advancing TurkishRussian economic relations.

However, no new political or economic initiatives were signed. There was no movement on the Blue Stream project, either. ${ }^{44}$ The Turkish government feels the pressure of gas-producing local players as well as the United States which views the project as an obstacle to developing a proposed trans-Caspian pipeline to transport Turkmen and Azeri natural gas to Turkey and beyond. The Blue Stream went back on course after the Duma passed legislation paving the way for a new Turkish-Russian protocol in late November on the technical aspects of the project.

Turkish public opinion is divided on the issue. Some argue that Turkey should reduce its dependence on Russia by multiplying its sources of supply; others view the Blue Stream as an important step to developing a strategic partnership with Russia. The Russians, meanwhile, fearful that the trans-Caspian line might doom the Blue Stream, voiced geological and environmental objections to the proposed line. But the Turkish government insists that the two pipelines are not mutually exclusive, as estimated future demand in Turkey could sustain both. ${ }^{45}$

Construction activity by Turkish firms is another important item in bilateral economic relations. According to Turkish official sources, the volume of this activity reached a total of $\$ 6.1$ billion in 1996 . The Turkish Eximbank has maintained since 1989 a credit line of $\$ 950$ million to help subsidize the work of Turkish businessmen in Russia. Construction is an area where the Russians feel that they are getting a raw deal, complaining that while Turkish companies in Russia have been awarded contracts to the tune of \$6-7 billion, Russian companies in Turkey have won contracts worth a mere $\$ 100$ million. ${ }^{46}$ In an interview with the Turkish Daily News, Russia's ambassador to Ankara, Alexander Lebedev, described this discrepancy as one of the persistent problems in bilateral relations. ${ }^{47}$

Russia has also been interested in arms exports to Turkey. ${ }^{48}$ Russian companies are reported to be keen on competing for the Turkish tender for 
the co-production of 145 modern helicopters at an estimated cost of $\$ 3.5$ billion. ${ }^{49}$

Another interesting development in Turkish-Russian relations is the remarkable growth in the number of Russian tourists visiting Turkey. According to Turkish statistics, apparently based on Russian sources, 1,048,000 Russian tourists reached Turkey in 1996. In 1995 and 1994, these numbers stood at 764,000 and 832,000 , respectively. Figures for 1999 dropped significantly due to fear of stepped-up PKK terrorism which did not happen - in the wake of PKK leader Abdullah Öcalan's capture in winter 1999 and the prolonged Russian economic crisis. Prospects for economic cooperation in the short term seem dim because everything from trade to tourism has been hit by the 1997 east Asian economic crisis and the August 1998 Russian financial collapse. ${ }^{50}$

\section{Conclusion}

Turkish-Russian relations in the 1990s have produced mixed results. On the positive side, economic cooperation reached record levels in a wide spectrum of activities ranging from trade to construction services to tourism, until external forces such as the east Asian and Russian financial crises forced cutbacks. On the negative side, over half a dozen politicalmilitary issues, described at the beginning of this article, remain outstanding and exacerbate the deep mistrust between these two geographically adjacent, but historically and culturally remote, regional powers.

Despite the mixed record of the recent past, there are grounds for both optimism and pessimism regarding future Turkish-Russian relations. The bilateral and multilateral political-military dialogue and economic cooperation that have engaged the two countries throughout the 1990s is a cause for optimism. However, Turks and Russians do not share a culture of dialogue. Historically, bilateral dialogues were rare and short-lived. The most significant case of a Turkish-Russian dialogue began during the Turkish war of independence and lasted for only two decades. Moscow signaled its intention to terminate that dialogue as early as 1938 , the year that generally marks the start of the Soviet-Turkish cold war. There were two primary reasons - one domestic and the other external - for Moscow's change of course. First, the Soviet socialist regime had successfully survived capitalist threats to its very existence and had succeeded in 
reconstructing a powerful new empire rationalized by a universalistic ideology. Second, the European state system was in danger of being overrun by the Nazis. Faced with these domestic and external circumstances, the Soviet Union looked beyond dialogue and cooperation with Turkey in order to bolster its domestic and external security.

Russian-Turkish relations of the 1990s show important similarities to those of the 1920s and 1930s. Russia's general weakness and vulnerability in the 1990s has left it with less foreign clout than it once enjoyed. In many ways, therefore, dialogue and cooperation are preordained forms of behavior, particularly with neighboring states of comparable power in a given time period. In other words, Turkish-Russian dialogue has been born largely out of necessity - out of Russia's unprecedented conventional weakness vis-à-vis Turkey. This necessity is true to some extent for Turkey as well, for the end of the Cold War has seen Turkey's growing exclusion and isolation from Europe. Relations with Russia have come to be seen as an important source of strength, if not an alternative, for Turkish foreign policy at a time when its position within Europe has come under serious challenge.

The current phase of Turkish-Russian dialogue and cooperation faces external challenges. Hostilities in the Balkans and the former Soviet republics in the 1990s have frequently drawn in Turkey and Russia, either directly or through smaller regional allies or local protégés. The Armenian-Azerbaijani conflict, the Chechen wars, and the PKK, for example, have all strained bilateral relations. One can conceive of a possible Russian-Turkish confrontation in the Caucasus, especially if ultra-nationalist forces in both countries wield power. The spread of the Chechen war to the southern Caucasus and Russia's penetration into Georgia and Azerbaijan through subversion and coup d'état are possible future scenarios.

For historical as well as geopolitical reasons, Russia and Turkey have backed opposing sides in the conflicts in the former Yugoslavia - Russia has stood behind Serbia and Turkey behind Bosnia and the Kosovars. A general war in the Balkans is likely to find them again on the opposing sides, perhaps fighting each other as members of opposing coalitions, as was the case in the past.

The risk of a Turkish-Russian confrontation triggered by regional conflicts, especially those in the Caucasus, would seem to be greater depending on the domestic circumstances in both countries. A slide to 
political radicalism in Russia as a result of continuing economic instability presents the most frightening risk to future bilateral relations. During the second Chechen war beginning in September 1999, Russia has revealed a return to hardline policies in dealing with conflict within its borders. Equally alarming is the support such policies have found among the Russian public. The recent hardline stance taken by Moscow both internally and towards the West is not a good omen for Russia's possible future responses to conflict along its borderlands in the new Eurasia.

These developments raise the key questions: Are we seeing the first phase of Russian neo-imperialism in the southern Caucasus, a goal which Moscow failed to achieve peacefully (through reintegration within the CIS) and which it might now be implementing through intimidation and perhaps the use of force? And, finally, would Russia employ methods of nuclear intimidation, the kind it resorted to in 1992 against Turkey, to bring the newly independent states in the southern Caucasus back into Moscow's fold?

\section{NOTES}

1. This power balance is essentially the result of the many-faceted weaknesses of the Newly Independent States (NIS) and the advantages that Russia enjoys as the former imperial ruler. The Soviet Union left a legacy, among other things, of infrastructural dependence on the former center and the seeds of ethnic conflict in numerous former Soviet republics as a result of unique nationality and intra-federation border policies pursued especially by Stalin. Karen Dawisha, a leading scholar in Soviet/Russian studies, wrote in 1995, at a time when Russia's new assertiveness in the former Soviet space gave rise to outside concerns about the possible revival of Russian imperialism, that Russia's continuing preeminence in Eurasia as the geographic colossus and economic power gives it enormous advantage but does not "naturally" lead to imperial ambitions over the new states. See "Conclusion: Imperialism, Dependence, and Interdependence in the Eurasian Space," in Adeed Dawisha and Karen Dawisha (eds.), The Making of Foreign Policy in Russia and the New States of Eurasia (Armonk, New York: M.E. Sharpe, 1995) This is Volume 4 of the ten-volume series, The International Politics of Eurasia, jointly edited by Karen Dawisha and Bruce Parrott.

2. There is increasing literature on Turkey's relations with central Asia and the southern Caucasus in the 1990s. See Patricia M. Carley, "Turkey and Central Asia: Reality Comes Calling," in Alvin Z. Rubinstein, and Oles M. Smolansky (eds.), Regional Power Rivalries in the New Eurasia: Russia, Turkey and Iran (Armonk, New York: M.E. Sharpe, 1995), pp.169--20I; Graham E. Fuller, "Turkey's New Eastern Orientation," in Graham E. Fuller and Ian O. Lesser (eds.), Turkey's New Geopolitics: From the Balkans to Western China (Boulder: Westview Press, 1993), pp.37-98; Heinz Kramer, "Will Central Asia Become Turkey's Sphere of Influence?" Perceptions (Ankara), (March-May 1996), pp.112-27; Rajan Menon and Henri J. Barkey, "The Transformation of Central Asia: Implications for Regional and International Security," Survival, Vol.34, No.4 (Winter 1992-93), pp.68-89, especially pp.76-8; Philip Robins, "Between Sentiment and Self-Interest: Turkey's Policy Toward Azerbaijan and the Central Asian States," Middle East Journal, Vol.47, No.4 (Autumn 1993), pp.593-610; Sabri Sayar, "Turkey, the Caucasus and Central Asia," in Banuazizi, Ali and 
Myron Weiner (eds.), The New Geopolitics of Central Asia and Its Borderlands (Bloomington, Indiana: Indiana University Press, 1994), pp.197-216; Duygu Bazoğlu Sezer, Turkey's Political and Security Interests and Policies in the New Geostrategic Environment of the Expanded Middle East, Occasional Paper, No.19 (Washington, DC: The Henry L. Stimson Center, July 1994), pp.9-17; Gareth, M. Winrow, Turkey in Post-Soviet Central Asia (London: The Royal Institute of International Affairs, 1995).

3. For leading Turkish sources on the history of Ottoman-Turkish relations, see Akdes Nimet Kurat, Türkiye ve Rusya 1798-1919 (Turkey and Russia 1798-1919) (Ankara: Ankara University Publication, 1970), and İsmail Hakkı Uzunçarşilı. Osmanlı Tarihi (The History of the Ottomans) (Ankara: Turkish Historical Society Publication, 1978). For a popular account in English see Lord Kinross, The Ottoman Centuries: the Rise and Fall of the Turkish Empire (New York: William Morrow and Co., 1977).

4. The following accounts of Kemalist foreign policy are notable for their extensive use of archival material and insiders' view, as they were authored by career diplomats working closely with the top decisionmaking circle: Yusuf Hikmet Bayur, Türkiye Devletinin Dls Siyaseti (The Foreign Policy of the Turkish State) (Ankara: Turkish Historical Society, 1973), and Aptulahat Aksin, Atatürk'ün Diş Politika llkeleri ve Diplomasisi (Ataturk's Foreign Policy Principles and His Diplomacy) (Ankara: Turkish Historical Society, 1991).

5. For the evolution of American policy towards Turkey in those years, see Bruce Kuniholm, Robellet, The Origins of the Cold War in the Near East (Princeton, New Jersey: Princeton University Press, 1980).

6. Mustafa Kemal Paşa, the leader of the War of Liberation, and Enver Paşa espoused opposing worldviews concerning the Ottoman entity. Therefore, they were political and ideological rivals. Mustafa Kemal in effect stood for the phasing out of the empire. Enver Paşa wanted, in a sense, to revitalize it. The former's victories against the enemy in 1919-22 removed Enver as a rival. A thoroughly political but defeated man, he moved on to Central Asia, but without a serious plan or aim. He drifted from one place to another in search of a confused dream of leading a Turkic union. In 1922 he and his small group of soldiers perished at the hands of an overpowering Bolshevik force on the skirts of the Pamir Mountains in Tajikistan. His remains were brought back to Turkey in 1993. For a popular account of Enver Paşa's place in the final days of the Ottoman empire and his sad finale in Turkistan, see his biography by well-known Turkish historian Sevket Süreyya Aydemir, Makedonya'dan Ortaasya ya Enver Paşa (Enver Pasha from Macedonia to Central Asia) (Istanbul: Remzi Kitabevi, 1972).

7. Serge A. Zenkovsky's pioneering work, Pan-Turkism and Islam in Russia (Cambridge: Harvard University Press, 1960), remains one of the classic scholarly works on the rise of nationalism among Turkic/Muslim peoples in Russia in the early twentieth century. For a study on ultra-nationalist movements in contemporary Turkey, see Jacob, M. Landau, PanTurkism: From Irredentism to Cooperation (Bloomington: Indiana University Press, Second Revised and Updated Edition, 1995). For Russian views by one of the leading Soviet/Russian experts on the subject of pan-Turkism and Turkey's presumable leading role in it, see Victor A. Nadeyin-Raevskiy, "Some Opinion on the Turkic Factor," in Nicolai A. Kovalsky (ed.), Russia: The Mediterranean and Black Sea Region (Moscow: Russian Academy of Sciences, Institute of Europe, 1996), pp.252-66; "Turtsia i Rossiyskiye Autonomi" (Turkey and Russian Autonomous Republics), in Irina Kabrinskaya and Sherman Garnett (eds.), Rossiya i Turtsia na Poroge XXI Veka: Na Puti v Evropu ili v Evrasiya? (Russia and Turkey on the Eve of the XXIst Century: On the Way to Europe or Eurasia?) (Moscow: Carnegie Endowment for International Peace, 1997), pp.69-83.

8. This term was first coined by the author in her chapter entitled, "Turkish-Russian Relations in the 1990s: From Adversity to Virtual Rapprochement," in Alan Makovsky and Sabri Sayan (eds.), Changing Dynamics of Turkish Foreign Policy (Washington, DC: Washington Institute for Near East Policy Press, forthcoming. Expected date of publication Spring 2000). The elaboration of the term offered in these pages also belongs to the author. 
9. Russian officials were visibly irritated in the early post-Soviet years at the intensification of relations between Ankara and the former Soviet republics. Hoping to keep the formers' loyalties fixed singularly on Moscow, they argued that CIS membership and alliances with other regional groupings were mutually exclusive. For example, Russian Federation Deputy Prime Minister Aleksandr N. Shokhin sent the following veiled warning to the Turkic states on the occasion of the Second Summit meeting of the Economic Cooperation Organization (ECO), founded by Turkey, Pakistan and Iran and joined in 1992 by the Islamic countries of the FSU: "Our friends from the commonwealth who, looking for better fortunes, are turning to the south should choose between closer economic integration with Russia and with their southern neighbors ... Clearly, one country cannot be a member of two customs unions." (The reference is to the new agreement among Russia, Belorussia and Ukraine for economic integration.). See "Three Slavic Ex-Soviet Lands to Press Economic Union," New York Times, July 15, 1993, p.15. See also "Central Asia to Decide Where to Join," FBIS-SOV-93-113 (July 14, 1999), p.6.

10. See Kemal Karpat for a rare example of a world-order approach to Turkey's relations with the southern NIS, in "The Role of Turkey and Iran in Incorporating the Former Soviet Republics into the World System," in Karen Dawisha (ed.), The International Dimension of Post-Communist Transitions in Russia and the New States of Eurasia (Armonk, New York: M.E. Sharpe, 1997). This is the final volume in a 10-volume monumental series entitled The International Politics of Eurasia, edited by Karen Dawisha and Bruce Parrott, pp.168-96.

11. Under Western and Turkish pressure, in Dec. 1998 the Greek-Cypriot government cancelled the decision to deploy the Russian missiles. Greece took delivery of the missiles for deployment in the island of Crete, thus effectively continuing to pose the same type of security threat to Turkey as the missiles' deployment in southern Cyprus would have done.

12. Dimitri Trenin, "Russia's Security Interests and Policies in the Caucasus Region," in Bruno Coppieters (ed.), Contested Borders in the Caucasus (Brussels: VUB University Press, 1996), p.91.

13. As this article went to press, the EU offered candidacy to Turkey at the Helsinki Summit held on Dec. 12, 1999.

14. Unofficial text of the treaty has been obtained from the Turkish ministry of foreign affairs in summer 1999

15. "Russia: Russia To Supply Natural Gas to Turkey," Moscow Interfax, Dec. 15, 1997, in FBIS-SOV-97-349, Dec. 15, 1997.

16. "Russia: Yılmaz-Turkey Seeks Cooperation, Not Rivalry with Russia," Moscow ITAR-TASS, Dec. 14, 1997, in FBIS-SOV-97-348, Dec. 14, 1997.

17. Ivan Navikov, "Russia: Chernomyrdin Previews Upcoming Trip to Turkey," Moscow ITARTASS, Dec. 11, 1997, in FBIS-SOV-97-345, Dec. 12, 1997.

18. "FP Asks Ecevit To Cancel Russia Trip Because of Chechnya," Ankara Anatolia, Nov. 2, 1999, in FBIS-WEU-1999-1102, Nov. 2, 1999, and, "Turkey: Islamists condemn antiterrorist agreement with Russia," Anatolia news agency, Nov. 7, 1999, in BBC Monitoring Service: Central Europe and Balkans, Nov. 9, 1999, in Reuters, Nov. 9, 1999.

19. 'Ecevit: Chechnya Russia's Problem, PKK Support on Agenda," Ankara Anatolia, Nov. 3, 1999, in FBIS-WEL"1999-1103, Nov. 3, 1999.

20. The official text of the agreement has not been disclosed by either side. For media accounts see "Premier concerned about Chechens, Russian support for Kurd rebels," BBC Monitoring Service: Central Europe and Balkans, Nov. 8, 1999, in Reuters, Nov. 8, 1999. The Turkish ministry of foreign affairs had earlier condemned the bomb attacks in Russia in Autumn 1999, expressing 'profound sorrow' for the losses of life. See, "Foreign Ministry Condemns 'Terrorist Attacks' in Russia," Ankara Anatolia, Sept. 10, 1999, in FBIS-WEU-1999-0910, $10 / 9 / 1999$.

21. 'Russia: Russian, Turkish premiers initial antiterrorism declaration in Moscow," ITAR-TASS new agency Nov. 5, 1999, in BBC monitoring former Soviet Union-political, 11/5/1999, in Reuters, Nov. 5, 1999.

22. Cengiz Çandar, a prominent Turkish columnist and a former Marxist, accused Turkish officials 
of having been manipulated by pro-Russian lobbies in and outside the government, and denounced the Ecevit visit as the betrayal of Chechens and of Turkish influence in the Caucasus by entering into the so-called anti-terrorist agreement at a time when the Russian government was engaged in an act of genocide against the Chechens. See Sabah, Nov, 6, 1999, p.21.

23. The Committee for Geopolitics has been chaired by Alexei Mitrofanov, member of the ultranationalist Liberal Democratic Party of Russia led by Vladimir Zhirinovsky. Zhirinovsky, who served as a party cell official at one of the industrial plants constructed in the 1970s in Turkey by the Soviet Union, has been the most outspoken voice of the anti-Turkey sentiments and policies in Russia since 1991. The Zhirinovsky -PKK connection was confirmed by Öcalan in his pre-trial interrogation and trial testimony in Turkey following his capture by Turkish authorities in Kenya in Feb. 1999. According to the Russian press, Mitrofanov personally brought Öcalan to Russia on Oct. 9, 1998, and the LDPR was behind the Duma's subsequent appeal to President Yeltsin for granting him political asylum. See, Nikolai Dmitriyev and Leonid Panin, "Russia: Öcalan Gives Away the Greeks and Zhirinovsky," Russia Izvestia, 1999, Russian Press Digest, Kommerstant, Feb. 23, 1999, in Reuters, Feb. 23, 1999. For more in the Russian press on the Duma's sympathies for the PKK leader Öcalan, see Turkish Probe, Oct. 25, 1999, in "Turkey: A New Phase in the Kurdish Problem," Reuters, Oct. 25, 1998.

24. 'Turkey: Russia's Primakov Pledges Not to Shelter PKK Leader," Ankara Anatolia, Oct. 29, 1998, in FBIS-WEU-98-302, Oct. 29, 1998; "Russia: Turkey Expects Russia to find, Oust, Kurdish Leader Öcalan," Moscow Interfax, Nov. 10, 1998, in FBIS-SOV-98-314, Nov. 10, 1998; "Turkey: Ambassador Says Relations with Russia 'Strengthened," Ankara Anatolia, Nov. 14, 1998, in FBIS-WEU-98-318, Nov. 14, 1998.

25. Reported from Moscow in Cumhuriyet (Turkish daily), Sept. 20, 1999

26. Dmitri Trenin, "Russia's Security Interests and Policies in the Caucasus Region," in Bruno Coppieters (ed.), Contested Borders in the Cancasus (Brussels: VUB University Press, 1996), p.91.

27. "Tensions Force Change in Military Doctrine," Foreign Broadcasts Information Service (henceforth FBIS)-SOV-93-048 (March 15, 1993), pp.66-7. While this analysis dates back to 1993 , its explanatory value is still relevant today, as little has changed in the basic thinking of the Russian political elite about the significance of the southern Caucasus for Russia's national security. It is generally believed that a report issued by Yevgeniy Primakov, then director of the Russian Foreign Intelligence Service, in Sept. 1994, openly charging Turkey and Iran of having aggravated the situation in the CIS "hot spots" by becoming "embroiled" in them in order to broader their influence and assert themselves as regional superpowers contributed to Turkey's negative image among the political elite. See. "Text of FIS Report Presented by Primakov," FBIS-SOV-94-185, Sept. 23, 1994, p.3.

28. L. Yermakova, "Russia's Federation Council Delegation to visit Caucasus," Reuters, Jan. 29 , 1998.

29. "Russia: Caucasus Region 'Biggest Serious Threat' to Russian Security-Minister", Reuters, April 8, 1998.

30. Liz Fuller, "Georgia/Turkey: Agreements Secure Bilateral Trade and Defence," March 10, 1999, http://search.rferl.org/nca/feaures/.

31. Ibid.

32. RFE/RL Newsline, Vol.3. No.138, Part I, July 19. 1999, and June 8, 1999.

33. It is not generally known, however, that Azerbaijan still houses Russia's strategic early warning station at Gaballa.

34. The International Institute for Strategic Studies, The Military Balance, 1900-2000 (London: Oxford University Press, 1999), p.90.

35. Moldova and Uzbekistan did not extend their memberships either. Ukraine has never joined the treaty, leaving Russia, Belorussia, Armenia, Kazakhstan, Kyrgyzstan, Turkmenistan, and Tajikistan as the seven parties to the renewed treaty.

36. "Russia: Russia, Armenia operate joint air defense station near Turkish border," Russia TV. 
Moscow, Feb. 22, 1999, BBC Worldwide Monitoring International Reports, Feb. 22, 1999, in Reuters Business Briefing, June 25, 1999.

37. On Russia's peacekeeping policies and practices, see the excellent work by Roy Allison, "Peacekeeping in the Soviet Successor States," Chaillot Papers 18 (Nov. 1994). See also A. Raevsky and I. N. Vorob'ev, Russsian Approaches to Peacekeeping Operations, Research Paper no. 28 (New York: United Nations Institute for Disarmament Research, 1994), and Lena Jonson and Clive Archer (eds.), Peacekeeping and the Role of Russia in Eurasia (Boulder, CO: Westview Press, 1996.)

38. The CFE treaty was signed in Paris in Nov. 1990, but the disintegration of the Soviet Union in Dec. 1991 forced new negotiations in 1992 to allocate the treaty-limited equipment belonging to the former Soviet Armed Forces among the former Soviet republics. The CFE treaty went into force in June 1992 upon the incorporation of the Tashkent treaty on the division of the Soviet forces. The disaggregation of the former Soviet armed forces into separate NIS forces affected Russia's equipment holdings especially in the flanks, meaning the Leningrad and the northern Caucasus military districts in the north and south respectively, due to the CFE treaty's limitations on treaty-limited equipment in these regions, known as the "flanks" in CFE parlance. Faced with internal and external instabilities in the Caucasus since the final years of the former Soviet Union, Moscow has constantly complained of the CFE's flank restrictions especially in the north Caucasus.

39. One theory suggests that the murders were prompted by a desire to thwart the signing at the Nov. 18-19, 1999 OSCE summit in Istanbul of a formal commitment by the Armenian and Azerbaijani presidents to pursue their effort to reach a Karabakh peace agreement and of the long anticipated agreement between Azerbaijan and Turkey to build the Baku-Ceyhan oil export pipeline. Azerbaijani prime minister Artur Rasizade said on a visit to Kazakhstan in mid-Oct. that the Baku-Ceyhan pipeline could be routed via Armenia if a Karabakh peace deal is cemented quickly. See Liz Fuller, "Cui Bono?" RFE/RL Services, CAUCASUS Report, Vol.2, No.43, Oct. 28, 1999, http:/www.rferl.org/caucasus.report/.

40. A rich literature has grown in the post-Soviet era on the regional and international implications of the political economy of Caspian Sea fossil fuels and their delivery arrangements to world markets, as the producing countries are all land-locked. For a useful, though somewhat dated, account of the main issues and alternative proposals for delivery networks, see Rosemarie Forsythe, "The Politics of Oil in the Caucasus and Central Asia," Adelphi Paper, 300 (London: International Institute for Strategic Studies, 1996). The most significant development in the second part of the 1990s has been the United States' more committal interest in the security and stability of the southern Eurasia in general and in the selection of the Baku-Ceyhan pipeline as the MEP for Azerbaijani oil.

41. Official trade figures were obtained from the Turkish ministry of foreign affairs in April 1999. It is important to note that Turkish and Russian figures somewhat vary possibly due to different accounting practices.

42. According to figures released by the Russian ministry of foreign economic relations, the volume of bilateral trade in 1997 reached close to $\$ 4$ billion, up 17 percent from the 1996 figure, with $\$ 2.1$ billion going for Russian exports to Turkey and $\$ 1.85$ billion for imports. See, "Russia: Chernomyrdin Previews Upcoming Trip To Turkey," Moscow ITAR-TASS, Dec. 11, 1997, in FBIS-SOV-97-345, Dec. 11, 1997.

43. Ivan Ivanov and Andrey Palariya, "Russia: Chernomyrdin Signs Gas Supply Agreement in Turkey," Moscow ITAR-TASS, Dec. 15, 1997, in FBIS-SOV-97-349, Dec. 15, 1997.

44. In an interview with ITAR-TASS, Prime Minister Ecevit attributed the failure to sign an additional protocol on the Blue Stream to the reluctance of the Duma to ratify an agreement on the prevention of double taxation and the promotion of investments. Quoted in Cenk Başlamıs, Milliyet, Nov. 7, 1999, p.18.

45. Ironically, Turkey faced severe power cuts for several days in early Dec. 1999 when gas deliveries by Russia fell below the agreed levels. It turned out that Russia's Gazprom lowered the natural gas amount it pumps to Ukraine in order to punish Ukraine for defaulting 
on payments to Russia. In effect Ukraine, one of the four countries through which the gas pipeline traverses before reaching the Turkish-Bulgarian border, punished Turkey by drawing above its own quota. Unsurprisingly, the Turkish public was angry but the government seemed to have deliberately avoided blaming Russian authorities with inefficiency or outright bad intentions. Instead, both Ecevit and President Demirel used the occasion to urge the speedy development of nuclear power, a project long debated but never seriously studied or pursued See "Turkey: Citing presidential support, Ecevit moves ahead with nuclear project..." in Turkish Daily News, Dec. 6, 1999, in Reuters, Dec. 6, 1999, http://wwwc.briefing.reuters.com/cgi.bin.

46. Andrey Palaria, "Russia: Russia Concerned Over Turkish-Russian Contract Imbalance," Moscow ITAR-TASS, Dec. 5, 1997, in FBIS-SOV-97-339, Dec. 5, 1997.

47. "Amb. Lebedev: No Place for Öcalan in Russia," Turkish Daily News (Ankara), Dec. 4, 1998.

48. "Russia: 'Source' Comments on Moscow-Ankara Military Trade," FBIS-SOV-96-244, 12/17/96, in Moscow INTERFAX, Dec. 17, 1996.

49. 'Russia: Russian Companies Among Bidders for Turkish Helicopter Tender," BBC monitoring service: former USSR 13/01/98, ITAR-TASS news agency, Jan. 5, 1998, in Reuters, Jan. 13, 1998.

50. It is important to note that acceleration in economic relations had begun during the final years of the Gorbachev leadership. Anatolii Chernishev, the last Soviet ambassador to Ankara who served in that post during the 1988-93 period, deserves credit for his ambitious lobbying soon upon arriving in Ankara with the Turkish business community in order to encourage it to invest in Russia. The Soviet government's decision in 1991 to award some Turkish companies the bid to construct a considerable portion of the new housing for Soviet troops being withdrawn from eastern Europe can easily be singled out for its profound influence on perceptions of Turkish businessmen of the Soviet Union/Russia as a land of opportunity. The Turkish business community has behaved since then as perhaps the most powerful proRussian lobby in Turkey. They have pressured governments to extend credits to Russia, to enter into major project deals such as the Blue Stream natural gas underwater pipeline, and have commissioned numerous studies. 
Copyright $@ 2002$ EBSCO Publishing 